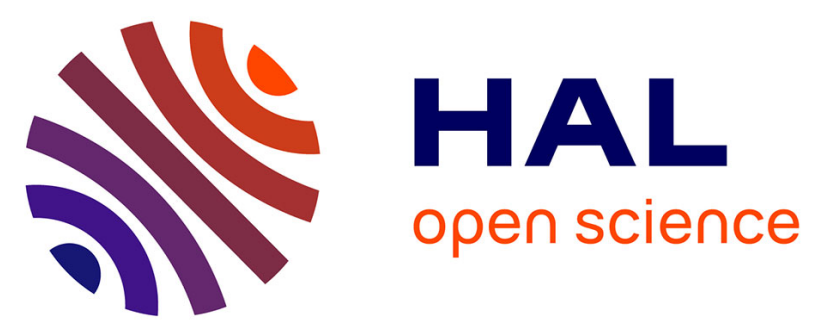

\title{
Identification of disinfection by-products in freshwater and seawater swimming pools and evaluation of genotoxicity
}

Tarek Manasfi, Michel de Meo, Bruno Coulomb, Carole Di Giorgio, Jean-Luc Boudenne

\section{To cite this version:}

Tarek Manasfi, Michel de Meo, Bruno Coulomb, Carole Di Giorgio, Jean-Luc Boudenne. Identification of disinfection by-products in freshwater and seawater swimming pools and evaluation of genotoxicity. Environment International, 2016, 88, pp.94-102. 10.1016/j.envint.2015.12.028 . hal-01436743

\section{HAL Id: hal-01436743 https://hal.science/hal-01436743}

Submitted on 26 Feb 2022

HAL is a multi-disciplinary open access archive for the deposit and dissemination of scientific research documents, whether they are published or not. The documents may come from teaching and research institutions in France or abroad, or from public or private research centers.
L'archive ouverte pluridisciplinaire $\mathbf{H A L}$, est destinée au dépôt et à la diffusion de documents scientifiques de niveau recherche, publiés ou non, émanant des établissements d'enseignement et de recherche français ou étrangers, des laboratoires publics ou privés. 


\title{
Identification of Disinfection By-products in Freshwater and Seawater Swimming Pools and Evaluation of Genotoxicity
}

\author{
Tarek Manasfi ${ }^{\mathrm{a}}$, Michel De Méo ${ }^{\mathrm{b}}$, Bruno Coulomb ${ }^{\mathrm{a}}$, Carole Di Giorgio ${ }^{\mathrm{b}}$, Jean-Luc Boudenne ${ }^{\mathrm{a}}$ \\ ${ }^{a}$ Aix Marseille Université, CNRS, LCE UMR 7376, 13331 Marseille, France \\ (E-mail: tarek.manasfi@univ-amu.fr; bruno.coulomb@univ-amu.fr; jean-luc.boudenne@univ-amu.fr) \\ b Aix Marseille Université, CNRS, IRD, Avignon Université, IMBE UMR 7263, Laboratoire de Mutagénèse \\ Environnementale, 13385, Marseille, France \\ (E-mail: michel.de-meo@univ-amu.fr; carole.di-giorgio@univ-amu.fr)
}

\begin{abstract}
Exposure to disinfection byproducts (DBPs) in swimming pools has been linked to adverse health effects. Numerous DBPs that occur in swimming pools are genotoxic and carcinogenic. This toxicity is of a greater concern in the case of brominated DBPs that have been shown to have substantially greater toxicities than their chlorinated analogues. In chlorinated seawater swimming pools, brominated DBPs are formed due to the high content of bromide. Nevertheless, very little data is reported about DBP occurrence and mutagenicity of water in these pools. In the present study, three seawater and one freshwater swimming pools located in Southeastern France were investigated to determine qualitatively and quantitatively their DBP contents. An evaluation of the genotoxic properties of water samples of the freshwater pool and a seawater pool was conducted through the Salmonella assay (Ames test). The predominant DBPs identified in the freshwater pool were chlorinated species and included trichloroacetic acid, chloral hydrate, dichloroacetonitrile, 1,1,1-trichloropropanone and chloroform. In the seawater pools, brominated DBPs were the predominant species and included dibromoacetic acid, bromoform and
\end{abstract}


dibromoacetonitile. Bromal hydrate levels were also reported. In both types of pools, haloacetic acids were the most prevalent chemical class among the analyzed DBP classes. The distribution of other DBP classes varied depending on the type of pool. As to genotoxicity, the results of Ames test showed higher mutagenicity in the freshwater pool as a consequence of its considerably higher DBP contents in comparison to the tested seawater pool.

\section{Keywords}

bromal hydrate; brominated compounds; chlorination; swimming pool; toxicity

\section{INTRODUCTION}

Disinfection of swimming pools is essential to reduce biological hazards related to the presence of pathogenic microorganisms that can cause infections to pool users. Several disinfectants are used for water disinfection in swimming pools such as chlorine-based disinfectants comprising gaseous chlorine, calcium hypochlorite, sodium hypochlorite, chlorinated isocyanurates, chloramines, and chlorine dioxide. An unintended consequence of treating water with these disinfectants is the formation of disinfection by-products (DBPs) due to reactions between the added disinfectant and organic matter present in water. To date, DBPs identified in swimming pool waters include haloamines, trihalomethanes (THM), haloacetic acids (HAA), haloacetonitriles (HAN), halodiacids, haloaldehydes, haloketones (HK), haloamides, halophenols, halobenzoquinones and $N$-nitrosamines (Richardson et al., 2010; Wang et al., 2013; Chowdhury et al., 2014; Teo et al., 2015). Chronic exposure to high levels of DBPs has been associated with adverse health effects, including irritations (eye, skin, nose and throat) (Fantuzzi et al., 2010; Font-Ribera et al., 2010), bladder cancer (Villanueva et al., 2004; Villanueva et al., 2007) and adverse reproductive effects 
(Nieuwenhuijsen et al., 2000; Hinckley et al., 2005). Many of the identified DBPs have been reported to be genotoxic and carcinogenic (Richardson et al., 2007). Furthermore, there is evidence suggesting that bromine-containing DBPs are more toxic than their chlorine-containing analogues (Hsu et al., 2001 ; Richardson et al., 2007; Plewa et al., 2008; Escobar-Hoyos et al., 2013). The formation of brominated DBPs takes place upon chlorination of bromide-containing waters. In such environments, bromine is the predominant disinfectant since bromide ions react with chlorine (hypochlorous acid) undergoing rapid oxidation to form hypobromous acid (Bougeard et al., 2010; Wang et al., 2010; Ged and Boyer, 2014). The influence of the $\mathrm{Br}^{-} / \mathrm{Cl}_{2}$ ratio was demonstrated to affect considerably the speciation of halogenated DBPs (Xue et al., 2008). In this way, pools filled with seawater, which has a high content of bromide up to 65 $\mathrm{mg} / \mathrm{L}$, are likely to generate brominated DBPs as predominant species (Parinet et al., 2012). Swimming pools filled with seawater can be found in thalassotherapy centers, which represent one of the rapidly growing sectors of medical and spa tourisms (Crecente et al., 2012). This sector dating back to the late 1800 s, originally involves the use of seawater and the marine environment as a source of therapy. However, modern thalassotherapy establishments have diverse categories of attendees encompassing curists as well as those merely seeking wellness (Schwartz, 2005). In these resorts, swimming pools are filled with seawater and treated with disinfectants similarly to freshwater swimming pools in order to eliminate waterborne pathogenic microorganism and prevent outbreaks of infectious diseases (WHO, 2006). In France, regulations recommend a free residual chlorine level between 0.4 and $1.4 \mathrm{mg} / \mathrm{L}$ when sodium hypochlorite (commonly called bleach) or chlorine gas are used as disinfectants disregarding the type of water filling the pool (ANSES, 2011). Many studies investigating the occurrence of DBPs in swimming pools filled with freshwater and municipal tap waters have been conducted and more than 100 DBPs were 
identified (Fantuzzi et al., 2001; De Laat et al., 2011; Chowdhury et al., 2014; Teo et al., 2015). Beech et al. (1980) investigated THM levels in 18 seawater swimming pools and identified bromoform as the dominant THM. Parinet et al. (2012) analyzed the occurrence of THMs and HAAs in seawater swimming pools and identified bromoform and brominated acetic acids as the predominant DBPs. However, data about the occurrence of brominated DBPs in seawater pools remain far less available than data reporting the occurrence of DBPs in freshwater pools. The characteristics of water in the seawater pools can influence the formation reactions of DBPs and result in different DBPs than those found in freshwater pools. In addition to high bromide content, seawater has a $\mathrm{pH}=8.0-8.5$, unlike freshwater where $\mathrm{pH}=7$. The effects of $\mathrm{pH}$ on the formation of DBPs have been put into evidence previously (Hansen et al., 2012). Furthermore, in spite of the evidence about the higher toxicity of brominated DBPs in comparison to their chlorinated analogues, no data can be found about the mutagenicity of seawater pools. In a study conducted by Richardson et al. (2010), the authors found that water samples obtained from chlorinated and brominated freshwater pools in Barcelona possessed mutagenic activities in Salmonella mutagenic assay.

Given the chemical risk concerns related to exposure to brominated DBPs, and the scarcity of data about their occurrence in seawater pools, this study aims at investigating the occurrence of DBPs, in three seawater pools and a freshwater pool, and to assess the mutagenicity of waters in the two types of pools. The present study involves an investigation in the Cote d'Azur region, France, in which we analyzed water samples obtained from three seawater pools of two thalassotherapy establishments and a freshwater pool. Chemical analyses involved the identification of DBPs, specifically THMs, HAAs, HANs, trihaloacetaldehydes (THAs) and HKs, and determining their levels in the four pools. Genotoxicity assessment involved the 
determination of the mutagenic potencies of water extracts of one of the seawater pools and of the freshwater pool, in the presence and absence of metabolic fraction S9 mix.

\section{MATERIALS AND METHODS}

\subsection{Study Site and Sampling}

The study was performed in three seawater swimming pools and a freshwater pool in two thalassotherapy establishments, designated as E1 and E2, located in the Cote d'Azur region in Southeastern France. Establishment E1 had an outdoor swimming pool filled with freshwater (Freshwater Pool E1) and an indoor pool filled with seawater (Seawater Pool E1) while E2 had two indoor pools filled with seawater, Seawater pool E2 (1) and Seawater Pool E2 (2). Seawater pools are filled with water originating from the Mediterranean Sea. Disinfection treatment involved the addition of sodium hypochlorite $(\mathrm{NaOCl})$ in an automated manner to maintain a constant level of free residual chlorine in the pools. In order to remove particulates and pollutants, the pools were equipped with sand filters. Sampling took place in summer 2014 and samples were collected from the four pools for TOC and DBP analyses and from two pools (freshwater and seawater) for mutagenicity assay. Physicochemical parameters such as temperature and $\mathrm{pH}$ were measured on-site. For DBP analysis, samples were collected in $65-\mathrm{mL}$ glass bottles filled without headspace and tightly sealed with a PTFE-lined screw cap. Prior to sampling, ascorbic acid of reagent grade (Sigma, China) was added in the sampling bottles to quench chlorine residual present in samples to avoid the alteration of the concentrations of DBPs due to reactions that could continue to take place following sampling (Kristiana et al., 2014). Another set of samples was collected in 1-L glass bottles for the analysis of total organic carbon (TOC). For the mutagenesis assay, samples of $30 \mathrm{~L}$ were collected from the freshwater and seawater pools of E1, 
without the addition of quenching agent to avoid any potential interference with Ames test. All the collected samples were stored at $4{ }^{\circ} \mathrm{C}$ away from sunlight until extraction.

\subsection{Physicochemical Parameters and DBPs Analysis}

Physicochemical parameters including $\mathrm{pH}$, electrical conductivity (EC), salinity, oxidation reduction potential (ORP) and oxygen saturation were determined on-site using specific electrodes from WTW (SenTix 41-3 pH electrode, WTW Pt 4805/S7 electrode, TetraCon 325 redox electrode, and CellOx 325 electrode, respectively). Residual chlorine and total chlorine were measured on-site by the colorimetric DPD method using a portable spectrophotometer (AQUALYTIC-AL 800, Germany). Non purgeable organic carbon (NPOC) was measured by catalytic oxidation at high temperature (Multi N/C 2100, Analytic Jena, Germany). The values of NPOC are referred to as total organic carbon (TOC) throughout the text. Bromide levels were measured with an ICS-3000 Dionex ion chromatography system using a $30 \mathrm{mM} \mathrm{NaOH}$ eluent with a flow rate of $1.5 \mathrm{ml} / \mathrm{min}$ at $30{ }^{\circ} \mathrm{C}$. The treatment of samples in order to determine target DBP contents varied depending on the chemical classes of DBPs and analyses were conducted in triplicate. To measure THMs, HANs, HKs, and THAs, samples were extracted by liquid-liquid extraction (LLE) with methy tert-butyl ether (MTBE) of Chromosolv, HPLC grade (SigmaAldrich, Germany) and analyzed by gas chromatography coupled to an electron capture detector (GC-ECD) (Perkin Elmer Clarus 580 system, Norwalk, CT, USA) based on U.S.EPA 551.1 (Munch and Hautman, 1995) with slight modifications. To measure HAAs, samples were treated and analyzed based on U.S.EPA 552.3 (Domino et al., 2003) with slight modifications. Sample aliquots were adjusted to a $\mathrm{pH}$ of 0.5 or less by adding sulfuric acid, analytical grade reagent (Fisher Scientific, UK) and then extracted with MTBE. Next, the organic phase containing the 
HAAs was treated with acidified methanol to form their corresponding methyl esters. The derivatized HAAs were analyzed with GC-ECD. Procedural standard calibration was used to quantify target analytes. More information on the preparation of calibration standards and DBP analyses can be found in Annexes (sections 2.1 and 2.2, respectively). Limit of detection (DL) and minimum reporting level (MRL) for each of the analyzed compounds are also reported in the supplementary material (Table S4).

\subsection{Mutagenesis Assay}

In order to determine the mutagenic properties of waters of the freshwater pool and the seawater pool of the same establishment E1, Ames test was conducted. Sample aliquots (30 L) from each of the two tested pools were acidified to a $\mathrm{pH}<1$ using sulfuric acid and then concentrated on a column containing two overlapping layers of thoroughly cleaned Supelite ${ }^{\mathrm{TM}}$ DAX-8 (Supelco, Bellefonte, PA, USA) over Amberlite ${ }^{\mathrm{TM}}$ XAD-2 (Supelco, Bellefonte, PA, USA) resins (Richardson et al. 2007). After loading the samples, the resins were eluted with $350 \mathrm{~mL}$ of ethyl acetate, LC-MS Chromasolv grade (Fluka Analytical, Germany). The resulting organic phase was then treated with sodium sulfate $\left(\mathrm{Na}_{2} \mathrm{SO}_{4}\right)$ of ACS reagent grade (Sigma-Aldrich, India) to remove any traces of water incorporated with ethyl acetate and then concentrated to $1.5 \mathrm{~mL}$ using TurboVap II Concentration Evaporator Workstation (Biotage). A $1 \mathrm{~mL}$ aliquot of this concentrate was analyzed using GC-ECD according to the methods mentioned previously to check whether the DBP families identified and quantified using LLE extracts were also present in it. A $0.5 \mathrm{~mL}$ aliquot of the resultant concentrate underwent solvent exchange to $0.5 \mathrm{~mL}$ dimethyl sulfoxide (DMSO) chromasolv plus (Sigma-Aldrich, UK). The 20,000x DMSO concentrates ( $0.5 \mathrm{~mL}$ of

DMSO corresponding to the equivalent of $10 \mathrm{~L}$ of the swimming pool water) were tested in 
triplicate using a micromethod of Ames test in Salmonella typhimurium strain TA100. The test was carried out in the presence and absence of rat liver enzyme-containing metabolic fraction S9 mix to check whether the metabolism of the extracted compounds could produce new genotoxic molecules. Four doses of each extract were tested. Sodium azide and benzo(a)pyrene were used as positive controls in the experiments without and with $\mathrm{S} 9$ mix, respectively. After $48 \mathrm{~h}$ of incubation, revertants (rev) were counted on each plate with an automatic colony counter equipped with a bacterial enumeration program (Scan 1200, Interscience, Saint Nom La Bretêche, France). The assay was performed in triplicate for each sample, and the mutagenic responses were expressed as the mean of the total number of revertants detected. The genotoxicity data were analyzed using the statistical and graphical functions of SigmaPlot (version 12.5) and Table Curve 2D (version 5.01) (SPSS Inc., Chicago, IL, USA). A two-step analysis was performed to interpret the data. The Dunnett test was primarily performed to determine a significant difference between the mean number of induced revertants and the mean number of spontaneous revertants. If the Dunnett test was positive for at least one sample concentration, a non-linear regression analysis was carried out using three arbitrary models as described previously (Di Giorgio et al., 2008) with TableCurve 2 software. Model significance was based on two criteria: (i) model probability $(\mathrm{P})$ being $<0.05$, and (ii) error probability $\left(\mathrm{P}_{\mathrm{ER}}\right)$ being $>0.05$. The Mutagenic Activity (MA, rev mL-eq) was defined as the maximal slope of the ascending part of the dose-response curve and was calculated as the first derivative at the origin.

\section{RESULTS AND DISCUSSION}

\subsection{Physicochemical parameters of swimming pool waters}


Table 1 lists the results of physicochemical analyses of waters from the four studied pools. The levels of free residual chlorine were similar in the four pools.

Table 1 - The physicochemical parameters of the four swimming pools are represented. PSU: Practical salinity unit.

\begin{tabular}{lllll}
\hline Swimming Pool & Freshwater & Seawater & Seawater & Seawater \\
& Pool E1 & Pool E1 & Pool E2 (1) & Pool E2 (2) \\
\hline $\mathrm{T}\left({ }^{\circ} \mathrm{C}\right)$ & 29.40 & 33.20 & 30.90 & 33.40 \\
$\mathrm{pH}$ & 7.00 & 8.54 & 8.46 & 8.32 \\
Salinity (PSU) & 1.15 & 51.87 & 44.55 & 44.32 \\
Bromide (mg/L) & 0.2 & 90.5 & 72.0 & 74.1 \\
TOC (mg/L) & 11.52 & 11.88 & 10.88 & 11.82 \\
Free Chlorine (mg/L) & 1.55 & 1.39 & 1.16 & 1.05 \\
Combined Chlorine (mg/L) & 0.29 & 0.11 & 0.16 & 0.10 \\
\hline
\end{tabular}

These levels were in agreement with the French regulations recommending a level of free chlorine between 1.0 and $1.4 \mathrm{mg} / \mathrm{L}$ except for the freshwater pool which had slightly higher levels $(1.5 \mathrm{mg} / \mathrm{L})$. TOC values were relatively high and of the same order of magnitude in the four swimming pools (arithmetic mean for the four pools $=11.52 \mathrm{mg} / \mathrm{L}, \mathrm{SD}=0.45$ ). In literature, higher TOC levels were reported in swimming pools. Thacker and Nitnaware (2003) reported levels of TOC up to $16 \mathrm{mg} / \mathrm{L}$ after chlorination in Indian swimming pools, and Chu and Nieuwenhuijsen (2002) reported TOC levels ranging from 3.3 to $12.9 \mathrm{mg} / \mathrm{L}$ in British swimming pools. TOC levels are conditioned by organic loads introduced to pools by users and by their activities inside the pools (Keuten et al., 2014). This anthropogenic origin of organic matter in the pools can be highlighted by the difference of TOC levels in raw seawater used to fill the pools ranging between 2 and $4 \mathrm{mg} / \mathrm{L}$ and levels measured in the pool ranging between 10.88 and 11.88 
$\mathrm{mg} / \mathrm{L}$. It should be noted that the sand filtration practiced on water before filling the pools reduces TOC below the levels found in raw water $(2.0 \mathrm{mg} / \mathrm{L}$ for seawater and $0.7 \mathrm{mg} / \mathrm{L}$ for freshwater). Temperatures of the pools ranged from 29.4 (freshwater pool) to $33.4{ }^{\circ} \mathrm{C}$ (pool 2 of E2). Unsurprisingly, salinity, expressed in practical salinity unit (PSU), varied considerably between freshwater (1.15 PSU) and seawater pools (mean value: 46.91 PSU). This latter value (higher than this of raw seawater -35 PSU-) may be explained by the extensive evaporation in seawater pools, where higher water temperatures were observed. Bromide content in the freshwater pool was 0.2 $\mathrm{mg} / \mathrm{L}$ while in the three seawater pools it reached $78.9 \mathrm{mg} / \mathrm{L}$ in average. $\mathrm{pH}$ also varied between the freshwater pool $(\mathrm{pH}=7.0)$ and the seawater pools $(\mathrm{pH}=8.3-8.5)$. The $\mathrm{pH}$ in the seawater pools slightly exceeds the maximum $\mathrm{pH}$ value recommended by French regulations according to which pH should be between 6.9 and 8.2 (ANSES, 2011). The other measured physicochemical parameters, besides those presented in table 1, can be found in Annex (table S1).

\subsection{Occurrence of DBPs in the swimming pools}

\subsubsection{Predominant species of DBPs}

The levels of the DBPs identified in the pools are presented in Table 2. Through this list, it appears clearly that the speciation of DBPs varied depending on the nature of water filling the pools. Although in all the pools chlorine was used for disinfection, brominated DBPs were the predominant species found in seawater pools while chlorinated DBPs were the predominant species in the freshwater pool. These findings are in agreement with previous studies which reported the formation of brominated DBPs in chlorinated bromide-containing water $(\mathrm{Wu}$ and Chadik, 1998; Hua et al., 2006; Wang et al., 2010; Ged and Boyer, 2014). In the presence of appreciable amounts of bromide ions, chlorine oxidizes bromide and forms hypobromous acid 
and hypobromite ions which in turn react with organic matter to form brominated DBPs (Singer, 1999). Bromine reacts 10 times faster with organic matter than chlorine (Westerhoff et al., 2004).

Table 2 - DBP levels (in $\mu \mathrm{g} / \mathrm{L}$ ) in the four swimming pools. The levels of the predominant DBP species in each pool are presented in bold.

\begin{tabular}{|c|c|c|c|c|c|}
\hline \multicolumn{2}{|c|}{ Swimming Pool } & $\begin{array}{l}\text { Freshwater } \\
\text { Pool E1 }\end{array}$ & $\begin{array}{l}\text { Seawater } \\
\text { Pool E1 }\end{array}$ & $\begin{array}{l}\text { Seawater } \\
\text { Pool E2 (1) }\end{array}$ & $\begin{array}{l}\text { Seawater } \\
\text { Pool E2 (2) }\end{array}$ \\
\hline \multirow[t]{5}{*}{ THM } & Chloroform & $69.8( \pm 4.1)$ & N.D. & N.D. & N.D. \\
\hline & Bromodichloromethane & $7.9( \pm 0.4)$ & N.D. & N.D. & N.D. \\
\hline & Dibromochloromethane & $1.9( \pm 0.4)$ & $3.9( \pm 0.2)$ & $5.2( \pm 0.3)$ & $1.6( \pm 0.2)$ \\
\hline & Bromoform & $0.6( \pm 0.5)$ & $62.5( \pm 6.7)$ & $86.7( \pm 2.1)$ & $48.9( \pm 1.7)$ \\
\hline & Total THM (THM-4) & $80.2( \pm 2.9)$ & $66.3( \pm 6.9)$ & $91.8( \pm 6.8)$ & $50.4( \pm 2.7)$ \\
\hline \multirow[t]{5}{*}{ HAN } & Dichloroacetonitrile & $74.6( \pm 8.5)$ & N.D. & N.D. & N.D. \\
\hline & Trichloroacetonitrile & $1.2( \pm 0.5)$ & N.D. & N.D. & N.D. \\
\hline & Bromochloroacetonitrile & $9.2( \pm 1.7)$ & $0.9( \pm 0.5)$ & $1.0( \pm 0.3)$ & $0.9( \pm 0.7)$ \\
\hline & Dibromoacetonitrile & $2.5( \pm 2)$ & $16.2( \pm 2.6)$ & $27.6( \pm 3.0)$ & $13.1( \pm 4.4)$ \\
\hline & Total HAN & $87.4( \pm 7.1)$ & $17.1( \pm 2.2)$ & $28.6( \pm 2.7)$ & $14.0( \pm 5.1)$ \\
\hline \multirow[t]{3}{*}{ HK } & 1,1-Dichloropropanone & $20.5( \pm 4.2)$ & N.D. & N.D. & N.D. \\
\hline & 1,1,1-Trichloropropanone & $71.9( \pm 7.9)$ & N.D. & N.D. & N.D. \\
\hline & Total HK & $92.4( \pm 1.9)$ & N.D. & N.D. & N.D. \\
\hline \multirow[t]{7}{*}{ HAA } & Monochloroacetic acid & N.D. & N.D. & N.D. & N.D. \\
\hline & Monobromoacetic acid & N.D. & $\underline{\mathrm{ND}}$ & $\underline{\mathrm{ND}}$ & $\underline{\mathrm{ND}}$ \\
\hline & Dichloroacetic acid & $23.0( \pm 6.6)$ & N.D. & N.D. & N.D. \\
\hline & Trichloroacetic acid & $461.1( \pm 27.9)$ & N.D. & N.D. & N.D. \\
\hline & Bromochloroacetic acid & $2.4( \pm 0.78)$ & $3.5( \pm 1.9)$ & $4.5( \pm 0.6)$ & $4.8( \pm 1.3)$ \\
\hline & Dibromoacetic acid & $1.7( \pm 0.6)$ & $72.0( \pm 6.4)$ & $62.8( \pm 14.1)$ & $63.5( \pm 33.0)$ \\
\hline & Bromodichloroacetic acid & $7.3( \pm 4.4)$ & N.D. & N.D. & N.D. \\
\hline
\end{tabular}




\begin{tabular}{llllll} 
& Dibromochloroacetic acid & $2.7( \pm 1.0)$ & $3.5( \pm 2.7)$ & $2.7( \pm 0.9)$ & $3.1( \pm 2.27)$ \\
Tribromoacetic acid & N.D. & $\mathbf{5 3 . 2}( \pm 3.7)$ & $\mathbf{3 9 . 0}( \pm 6.1)$ & $\mathbf{3 5 . 6}( \pm 5.8)$ \\
THA & Total HAA (HAA-9) & $498.3( \pm 35.7)$ & $132.3( \pm 14.6)$ & $108.9( \pm 13.2)$ & $107.0( \pm 5.7)$ \\
& Chloral hydrate & $\mathbf{1 9 0 . 2}( \pm 6.5)$ & N.D. & N.D. & N.D. \\
HNM & Bromal hydrate & N.D. & $2.2( \pm 0.3)$ & $1.0( \pm 0.3)$ & $0.4( \pm 0.1)$ \\
& Chloropicrine & $4.5( \pm 0.6)$ & N.D. & N.D. & N.D. \\
\hline
\end{tabular}

\begin{abstract}
N.D.: Not determined, this refers to compounds which were not detected or which were detected at levels below the corresponding minimum reporting level (MRL).

THM: trihalomethane; HAN: haloacetonitrile; HK: haloketone; HAA: haloacetic acid;

THA: trihaloacetaldehyde; HNM: halonitromethane
\end{abstract}

The reactions leading to the formation of bromine in bromide-rich water are as follows (Heeb et al., 2014):

$$
\begin{array}{ll}
\mathrm{HOCl}+\mathrm{Br}^{-} \rightarrow \mathrm{HOBr}+\mathrm{Cl}^{-} & \mathrm{k}_{1}=(1.55-6.84) \cdot 10^{3} \mathrm{M}^{-1} \mathrm{~s}^{-1} \\
\mathrm{ClO}^{-}+\mathrm{Br}^{-} \rightarrow \mathrm{BrO}^{-}+\mathrm{Cl}^{-} & \mathrm{k}_{2}=9.10^{-4} \mathrm{M}^{-1} \mathrm{~s}^{-1}
\end{array}
$$

The predominant species of DBPs found in the two types of pools are presented in bold in Table 2. In seawater and freshwater pools, the dominant THMs and HANs were analogous compounds with the molecular difference being the nature of halogen incorporated in the compound (chlorinated versus brominated forms). In this way, among THMs chloroform was the most abundant species in the freshwater pool $(69.82 \mu \mathrm{g} / \mathrm{L}$, representing $87 \%$ of THM-4) versus bromoform (mean level for the three seawater pools: $65.9 \mu \mathrm{g} / \mathrm{L}, \mathrm{SD}=19.1$, representing $95 \%$ of THM-4) in the seawater pools (Figure S1, Section 3 in the Supporting Information). For HANs, dichloroacetonitrile $(74.6 \mu \mathrm{g} / \mathrm{L}, \mathrm{SD}=8.5$, corresponding to $85.4 \%$ of $\mathrm{THAN})$ was the predominant HAN in the freshwater pool, versus dibromoacetonitrile $(19.0 \mu \mathrm{g} / \mathrm{L}, \mathrm{SD}=7.6$, corresponding to $95.3 \%$ of THAN) in the seawater pools (Figure S2, Section 3 in Annex). This trend in analogy between the predominant DBPs in freshwater and seawater pools did not apply in 
the case of HAAs. Trichloroacetic acid was the most abundant HAA in the freshwater pool (461.1 $\mu \mathrm{g} / \mathrm{L}$, corresponding alone to $92 \%$ of HAAs-9) versus dibromoacetic acid followed by tribromoacetic acid in the seawater pools (mean levels: $66.1 \mu \mathrm{g} / \mathrm{L}, \mathrm{SD}=5.2$ and $42.6 \mu \mathrm{g} / \mathrm{L}, \mathrm{SD}=$ 9.3, corresponding to $57 \%$ and $36.3 \%$ of HAA-9, respectively) (Figure 1). This could be related to the lower stability of tribromoacetic acid with respect to dibromoacetic acid while trichloroacetic is a stable HAA (Zhang and Minear, 2002; Lifongo et al., 2010; Cardador and Gallego, 2015). It has been reported that tribromoacetic acid may decompose to form the corresponding THM, bromoform, in aqueous solutions (Zhang and Minear, 2002).

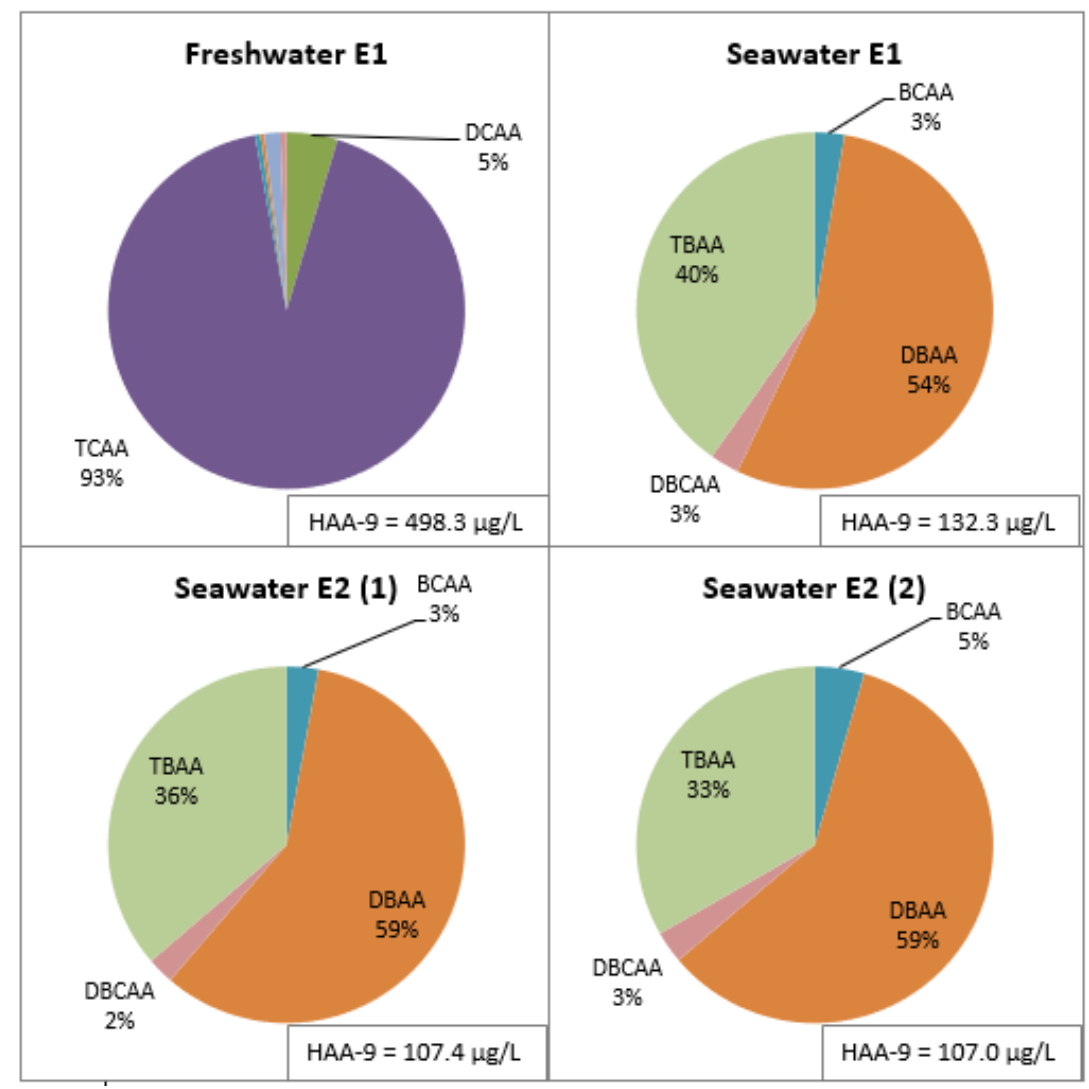

Fig. 1 - Distribution patterns of HAAs in the freshwater pool and the seawater pools under study. Percentages indicate the mass abundance of each HAA with respect to HAA-9 - the sum of concentrations of all the HAAs identified in each pool. The concentration below each pie chart represents HAA-9.

DCAA: dichloroacetic acid; TCAA: trichloroacetic acid; DBAA: dibromoacetic acid; TBAA: tribromoacetic acid; BCAA: bromochloroacetic acid; DBCAA: dibromochloroacetic acid 
These distributions for the major brominated DBPs are in agreement with the findings of Hua et al. (2006) who suggested that bromine substitution into THM and DHAN is more efficient than into HAAs. Among HKs identified in the freshwater pools, 1,1,1-trichloropropanone was the predominant DBP with a level of $71.9 \mu \mathrm{g} / \mathrm{L}$ (corresponding to $77.8 \%$ of total HK) and to a lower extent 1,1-dichloropropanone with a level of $20.5 \mu \mathrm{g} / \mathrm{L}$. Previously, Richardson et al. (2010) identified 1,1,1-trichloropropanone in all the samples obtained from a chlorinated freshwater pool and 1,1-dichloropropanone in two out of five samples from the same pool. Similarly, Yeh et al. (2014) detected low levels of 1,1-dichloropropanone while the concentrations of 1,1,1trichloropropanone were close to $10 \mu \mathrm{g} / \mathrm{L}$. Very few quantitative data about the occurrence of haloketones in swimming pools could be found in literature while this class of DBPs was reported to be among the most prevalent DBPs in drinking water (Xu et al., 2002).

Our findings about the prevalent DBPs in the freshwater pool are in agreement with other studies in this type of pools in which chloroform, trichloroacetic acid, and dichloroacetonitrile have been reported as the predominant species of THMs, HAAs and HANs, respectively (WHO, 2006; Lee et al., 2010; Simard et al., 2013; Righi et al., 2014). Similarly, our findings in the seawater pools concerning the predominance of bromoform, and dibromoacetic acid/tribromoacetic acids as the major THMs and HAAs, respectively, are in agreement with the very little data reported in literature about this type of pools (Beech et al., 1980; Parinet et al., 2012). The predominance of bromoform was also previously reported in brominated freshwater pools (Lourencetti et al., 2012). With regard to HANs, according to our knowledge, the levels of dibromoacetonirile in seawater swimming pools were previously reported only once in a study of indoor seawater pools in Germany where a level of $49 \mu \mathrm{g} / \mathrm{L}$ was reported (Baudisch et al., 1997), while the levels of 
bromochloroacetonitrile in chlorinated seawater swimming pools were reported for the first time in the present study.

Interestingly, the trihaloacetaldehyde bromal hydrate (trihaloacetaldehydes exist in their hydrated forms in water) was detected at very low concentrations in the seawater pools with a mean level of $1.2 \mu \mathrm{g} / \mathrm{L}(\mathrm{SD}=0.9)$, whereas in the freshwater pool chloral hydrate $(190 \mu \mathrm{g} / \mathrm{L})$ represented the second most abundant DBP following trichloroacetic acid $(461.1 \mu \mathrm{g} / \mathrm{L}$ ), as shown in Table 2 (and Figure S3, Section 3, in the Annex). In literature, chloral hydrate was identified as a minor chlorination product of aromatic species such as 1,3-dihydroxybenzene (Rook, 1980; Boyce and Hornig, 1983). In a recent study, bromal hydrate was detected in reconstituted seawater as a minor chlorination product of a widely used chemical UV filter (Manasfi et al., 2015). Chloral hydrate was previously reported to be among the most abundant DBPs in chlorinated freshwater pools with levels reaching up to $380 \mu \mathrm{g} / \mathrm{L}$ (Clemens and Schöler, 1992; Cimetiere and De Laat, 2014). Lower levels were also reported for this compound in Korean chlorinated freshwater pools with concentrations ranging from $5.1 \mu \mathrm{g} / \mathrm{L}$ to $34.9 \mu \mathrm{g} / \mathrm{L}$ (Lee et al., 2010). Unlike chloral hydrate, bromal hydrate occurrence levels are very scarcely reported in literature. Baudisch et al. (1997) reported a level of bromal hydrate reaching $230 \mu \mathrm{g} / \mathrm{L}$ in German seawater swimming pools, as mentioned in the WHO report about recreational water guidelines (WHO, 2006). This discrepancy in the occurrence of trihaloacetaldehydes in swimming pools may be related to the compromised stability of these compounds. Trihaloacetaldehydes decompose to their corresponding trihalomethanes (THMs) at high $\mathrm{pH}$ and temperature (Koudjonou and LeBel, 2006). In our study, the seawater pools had relatively high temperatures and basic $\mathrm{pH}$, which might explain the low levels of bromal hydrate in these pools unlike the more stable chlorinated analogue chloral hydrate in the freshwater pool. In a study of the molecular structures of these 
two compounds, Jain and Soundararajan (1964) found that bromal hydrate is less stable than chloral hydrate.

Chloropicrin (trichloronitromethane), a halonitromethane classified among the high priority DBPs by EPA's nationwide DBP occurrence study based on its potential toxicity (Weinberg et al., 2002), was detected in the freshwater pool at a level of $4.5 \mu \mathrm{g} / \mathrm{L}$. Other studies also reported the occurrence of this DBP in swimming pools at levels ranging from 0.01 to $10 \mu \mathrm{g} / \mathrm{L}$ (WHO, 2006).

\subsubsection{Distribution patterns of DBP classes}

The distribution of the different DBP chemical classes and the abundance of each class with respect to the global content of DBPs (mass/mass) in the freshwater pool and the seawater pools (arithmetic mean for the three pools) are displayed in figure 2. The levels of DBP species belonging to the separate chemical classes were added together so that the total level for each class is represented in $\mu \mathrm{g} / \mathrm{L}$. In the four pools the most abundant class of DBPs was HAAs with a level of HAA-9 (sum of concentrations of the nine HAAs) as high as $498.3 \mu \mathrm{g} / \mathrm{L}$ in the freshwater pool and a mean level of $116.1 \mu \mathrm{g} / \mathrm{L}(\mathrm{SD}=14.1)$ in the seawater pools. HAA-9 represented $53 \%$ of the total mass concentration of DBPs in the freshwater pool and $56 \%$ in the seawater pools (mean value for the three seawater pools). Unlike HAAs, the other DBP classes had different distribution patterns in terms of their abundance depending on the nature of water filling the pool (freshwater or seawater). 

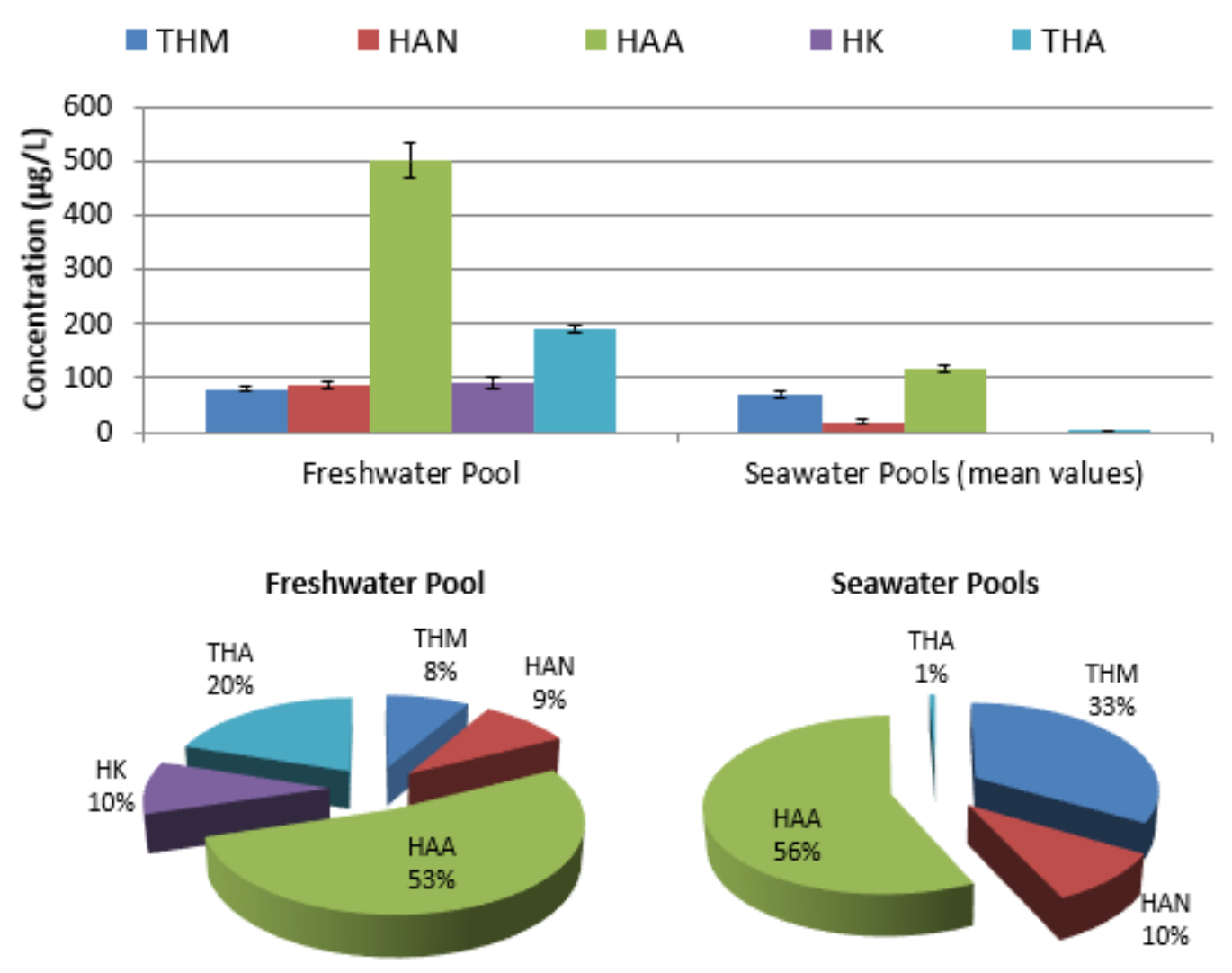

Fig. 2 - The distribution of the different chemical classes of DBPs in the freshwater pool and the seawater pools (arithmetic mean values for the three pools are indicated). Percentages in the pie charts indicate the mass abundance of each DBP class with respect to the total DBP content

Among the DBP classes measured in the seawater pools, THMs were the second most prevalent class (mean level in the three pools THM-4: $69.5 \mu \mathrm{g} / \mathrm{L}, \mathrm{SD}=2.7$, corresponding to $33 \%$ of the measured DBPs) followed by HANs (mean level: $19.9 \mu \mathrm{g} / \mathrm{L}, \mathrm{SD}=7.6$, corresponding to $10 \%$ of the measured DBPs). On the other hand, the distribution was different in the freshwater pool. In the latter, trihaloacetaldehydes (chloral hydrate) represented the second most abundant class of DBPs with a level of $190.2 \mu \mathrm{g} / \mathrm{L}(\mathrm{SD}=6.5)$ corresponding to $20 \%$ of the measured DBPs in the pool. HKs were identified at high levels in the freshwater pool and represented the third most abundant DBP class with total $\mathrm{HK}=92.4 \mu \mathrm{g} / \mathrm{L}, \mathrm{SD}=11.9$ corresponding to $10 \%$ of the measured DBPs. HANs were the fourth most abundant DBP class (Total HAN: $87.4 \mu \mathrm{g} / \mathrm{L}, \mathrm{SD}=7.1$, 
corresponding to 9\%), and THMs represented the least abundant class of DBPs with THM-4 = $80.2 \mu \mathrm{g} / \mathrm{L}, \mathrm{SD}=2.9$, corresponding to $9 \%$ of the measured DBPs. The distribution pattern for HAAs and THMs in seawater is in agreement with the findings of another study conducted in seawater swimming pools in which contents of HAAs were considerably higher than THMs (Parinet et al., 2012). Similar to studies investigating the presence of DBPs in chlorinated freshwater pools, HAAs were identified as the most abundant class (Lee et al., 2010; Simard et al., 2013; Righi et al., 2014; Yeh et al., 2014). This prevalence of HAAs with respect to THMs in swimming pools could be explained, in part, by their physicochemical properties. THMs are volatile compounds which had been reported to occur in higher concentrations in air above swimming pools than in water (WHO 2006, Richardson et al. 2010), while HAAs are polar compounds with low volatility (Cardador and Gallego, 2011). Furthermore, the type of organic compounds acting as precursors for the formation of DBPs in swimming pools affects the nature of the formed by-products. Kanan and Karanfil (2011) found that body fluid analogues, a synthetic formulation simulating human body fluid inputs, exhibited higher formation potential of HAAs than THMs. Thus, taking into consideration the anthropogenic inputs released by swimmers (Keuten et al., 2012), this can explain in part why more HAAs than THMs were found. The freshwater pool contained higher levels of HANs (total HAN: $87.37 \mu \mathrm{g} / \mathrm{L}$ ) and HAAs (HAA9: $498.3 \mu \mathrm{g} / \mathrm{L}$ ) in comparison to the three seawater pools that had mean levels of $19.9 \mu \mathrm{g} / \mathrm{L}$ for HANs and $116.1 \mu \mathrm{g} / \mathrm{L}$ for HAA-9. This corresponds to nearly four-fold higher contents of HAAs and HANs in freshwater compared to the three seawater pools. However, the contents of THMs (THM-4) in the freshwater pool did not follow the same ratio; only a level of $80.2 \mu \mathrm{g} / \mathrm{L}$ (arithmetic mean), $\mathrm{SD}=2.9$ was quantified in the freshwater pool versus $69.5 \mu \mathrm{g} / \mathrm{L}, \mathrm{SD}=20.8$ in the three seawater pools. This lag of THMs with respect to HANs and HAAs which occurred at 
four-fold higher levels in the freshwater pool compared to the seawater pools might be related to several factors including location of the pools, physicochemical properties of DBPs, activities of pool users and $\mathrm{pH}$. The location of pools, indoor or outdoor, can have an impact on the levels of certain DBPs. An outdoor setting increases volatilization and therefore reduces the concentrations of volatile DBPs such as THMs in water, and it enhances the degradation of photosensitive species upon exposure to direct sunlight (Zwiener et al., 2007; Liviac et al., 2010; Yeh et al., 2014). With regard to the effect of the physicochemical properties of DBPs, chloroform -the main THM in chlorinated freshwater pools- is more volatile than bromoform, even when comparing the volatility of chloroform in freshwater with the volatility of bromoform in seawater (Moore et al., 1995). Thus, chloroform would be expected to evaporate more readily from the pool surface (Beech et al., 1980). It should be noted that in the freshwater pool investigated in this study, users included children and adults among whom there were individuals engaging in activities causing hydraulic turbulences inside the pool. The activity of pool users is a factor that enhances the volatilization of THMs from the pools (WHO, 2006). Moreover, the lower $\mathrm{pH}$ of freshwater compared to seawater is one of the factors that influence the formation and speciation of DBPs. In a study investigating the effects of $\mathrm{pH}$ on the formation of DBPs in swimming pools, Hansen et al. (2012) found that at as $\mathrm{pH}$ decreased, THM formation was reduced while HAN formation increased and HAA formation remained constant. All these factors could explain why THMs in the freshwater pool did not follow the same scale of abundance as HANs and HAAs (4 folds) compared to the seawater pools. In this limited study it is not possible to discriminate the factors that are leading to the observed distributions of DBPs especially with the complexity of environments like swimming pools. Further research is necessary to decipher the impact of these different factors on the classes of DBPs. 
Globally, the freshwater pool had higher DBP content than the seawater pools $(948 \mu \mathrm{g} / \mathrm{L} v s$ mean value of $208 \mu \mathrm{g} / \mathrm{L}, \mathrm{SD}=31$, respectively). Knowing that management strategies of the studied pools were similar as indicated by pool operators, the difference in DBP contents seems to be related to different frequentation rates between the pools. Swimmers in the freshwater pool noticeably outnumbered those in the seawater pools. The continuous introduction of organic matter by swimmers to pools is known to increase the formation of DBPs (Kim et al., 2002). Previously, a clear positive correlation was established between the number of people in swimming pools and DBP concentrations (Chu and Nieuwenhuijsen, 2002). Recently, Keuten et al. (2014) estimated important releases of anthropogenic organic matter from swimmers with considerable portions of nitrogen-containing compounds.

\subsection{Mutagenicity of swimming pool waters}

The results of Ames test conducted on the reference freshwater pool and the seawater pool (E1) showed that water samples from the freshwater pool were mutagenic $(3.7 \mathrm{rev} / \mathrm{mL}-\mathrm{eq})$ and showed higher mutagenic activity than the seawater pool which was found to be weakly mutagenic $(0.4$ rev/mL-eq). The presence of the metabolic fraction S9 mix decreased the mutagenic potencies of samples to $1.8 \mathrm{rev} / \mathrm{mL}$ and $0.3 \mathrm{rev} / \mathrm{mL}$ for the freshwater and the seawater pools, respectively. This decrease suggests that the compounds exerting the mutagenic activity were mainly direct mutagens that could be detoxified by metabolism, as shown in previous studies also (Neale et al., 2012; Farré et al., 2013; Yeh et al., 2014). The genotoxic potencies in presence and absence of S9 mix are presented in Table 3. The dose-response curves for waters of the two pools, in the absence of S9 mix, are presented in figure 3. As described in this figure, the mutagenic effects 
increased as a function of water volume expressed in $\mathrm{mL}$-eq. However, in the case of freshwater pool samples, the detected mutagenic effects started to decrease at high doses ( $>150 \mathrm{~mL}$-eq).

Table 3 - The mutagenic potencies of swimming pool water in the presence and absence of S9 mix and the total molar content of DBPs in the corresponding pool

\begin{tabular}{|c|c|c|c|}
\hline & & Freshwater Pool & Seawater Poo \\
\hline \multicolumn{2}{|c|}{$\begin{array}{l}\text { Total Molar Content of DBPs } \\
\text { (mol/L) }\end{array}$} & 5.69 & 0.91 \\
\hline \multirow{2}{*}{$\begin{array}{l}\text { Mutagenic Potency } \\
\text { (rev/mL-eq) }\end{array}$} & Without S9 mix & 3.7 & 0.4 \\
\hline & With S9 mix & 1.8 & 0.3 \\
\hline
\end{tabular}

This can be related to the presence of high concentrations of genotoxic compounds that overloaded the DNA repair systems and resulted in cytotoxic effects. Another alternative is the presence of true cytotoxic molecules that prevented the detection of higher mutagenic effects at these doses; especially that among DBPs there are species known to be cytotoxic but not mutagenic (Richardson et al., 2007; Richardson et al., 2010). Although brominated DBPs are generally known to be more genotoxic than chlorinated ones (DeMarini et al., 1997; Richardson et al., 2007; Plewa et al., 2008; Kogevinas et al., 2010), our findings about the higher mutagenicity of the freshwater pool remain unsurprising. This pool, containing mainly chlorinated DBPs, had considerably higher DBP contents than the seawater pool, containing mainly brominated DBPs. As revealed through the chemical analysis, the freshwater pool had about sixfold higher molar content of DBPs (total DBP molar concentration: $5.69 \mu \mathrm{mol} / \mathrm{L}$ ) than the seawater pool (total DBPs molar concentration: $0.91 \mu \mathrm{mol} / \mathrm{L}$ ). Among the identified DBPs there are species that are known to be mutagenic such as HANs (Richardson et al., 2007) which were found at higher concentrations in the freshwater pool than the seawater pool. 


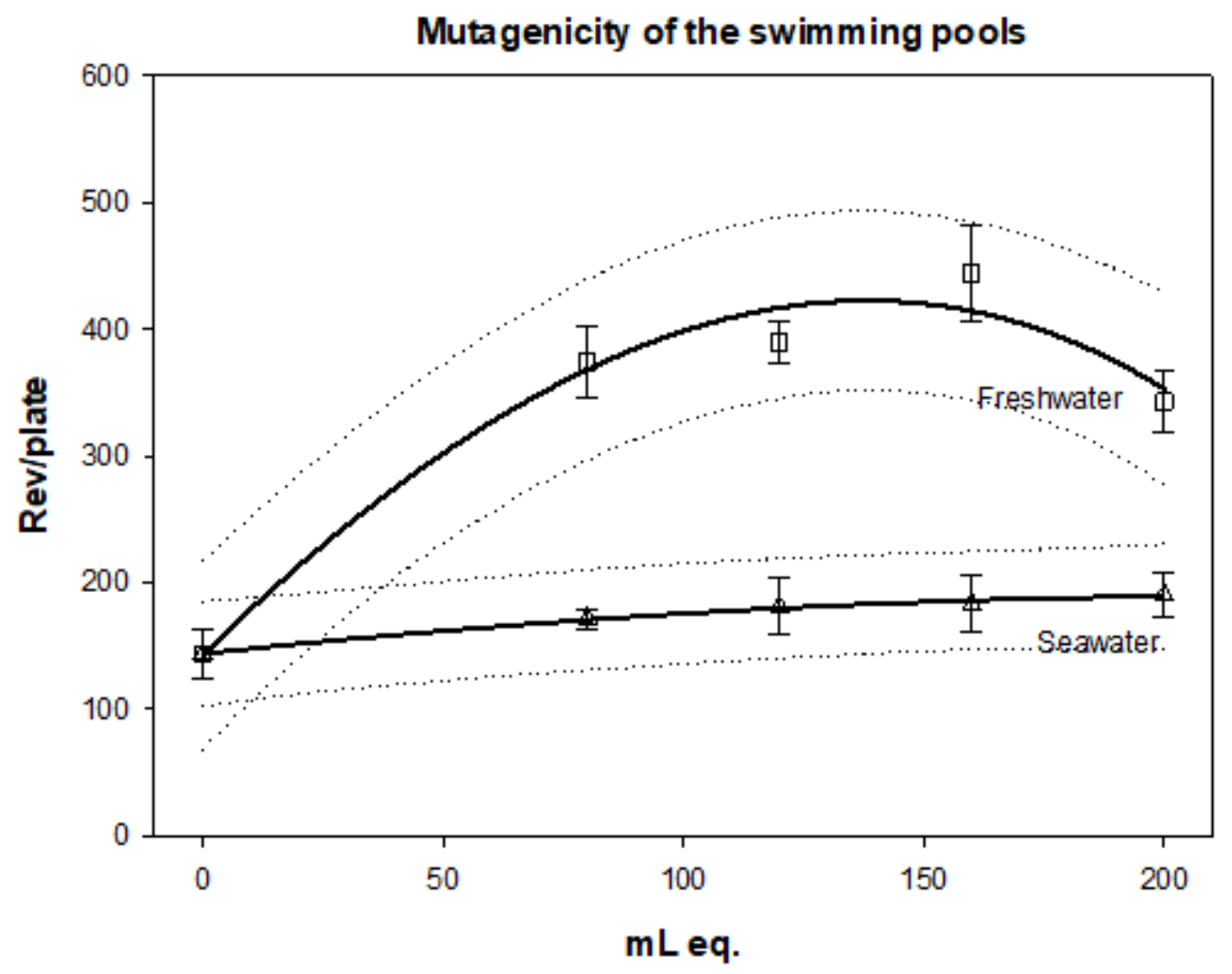

Fig. 3 - Mutagenicity in Salmonella TA100 of freshwater and seawater pools samples in the absence of the metabolic fraction $\mathrm{S9}$

In an investigation of the genotoxicity of swimming pool water, Glauner et al. (2005) found that the low-molecular-weight fraction of extracts from pools in Germany possessed the strongest genotoxicity compared to the other fractions. In another study comparing the genotoxicities of DBP chemical classes, Plewa et al. (2008) found that nitrogen-containing DBPs including haloacetonitriles, haloacetamides, halonitromethanes had substantially higher genotoxicities and cytotoxicities compared to carbonaceous DBPs including HAAs and THMs. In our investigation, however, the observed mutagenic activity cannot be attributed to specific DBP classes or to the identified DBPs only, because pool extracts are complex mixtures, and the presence of unidentified chemical mutagens cannot be excluded. In addition, the sample preparation for mutagenicity assessment using XAD resins resulted in a concentration factor of 20000 folds, as 
previous studies that investigated toxicological properties of swimming pool waters; while identification and quantification of DBPs was performed using 10-fold LLE concentrates according to EPA methods. While the concentration factor obtained with LLE is not high enough to perform the bioassay, the sample preparation with XAD extraction engenders losses in volatile DBPs especially during the volume reduction of the solvent (Richardson et al., 2008; Neale et al., 2012). The analysis of the XAD extracts by GC-ECD confirmed these quantitative losses in volatile DBPs as illustrated in table S5 (Annexes section 3). Losses were also reported to take place with other sample preparation techniques such as reverse osmosis and using SPE cartridges (Richardson et al., 2008; Neale et al., 2012). In this way, our correlation between the chemical characterization and the bioassay cannot exceed the qualitative aspects of relating the higher mutagenicity to a globally higher DBP content. Furthermore, the genotoxicity of water can be affected by the pool location since an outdoor pool setting reduces genotoxic properties of its waters due to volatilization and photodegradation of certain DBPs (Liviac et al., 2010; Yeh et al., 2014). However, despite its outdoor location, the freshwater pool which was more frequented exhibited higher mutagenicity than the indoor seawater pool. This suggests that DBP contents as a consequence of frequentation rates in swimming pools constitute a key factor in determining the genotoxicity of water, dominating other factors such as the nature of water filling the pool and its location. Further investigations are necessary to distinguish the extent to which each one of these factors can alter the chemical profile of swimming pool waters and their genotoxic potencies.

\section{CONCLUSION}

This investigation allowed the determination of the occurrence of numerous DBPs in three seawater indoor swimming pools and a freshwater outdoor pool which were disinfected with 
chlorine. The measured DBPs included THMs, HAAs, HANs, two chlorinated ketones, and trihalogenated acetaldehydes. Levels of DBPs in seawater swimming pools - for which occurrence data in literature are scarce- were reported in this study. Levels of certain DBPs in seawater swimming pools were reported for the first time. The speciation of DBPs varied depending on the nature of water filling the pools. Brominated DBPs were predominant in the seawater pools while chlorinated DBPs were predominant in the freshwater pool. Dibromoacetic acid, tribromoacetic acid, bromoform and dibromoacetonitrile were the predominant DBPs in the seawater pools. Trichloroacetic acid, dichloroacetic acid, chloral hydrate, 1,1,1trichloropropanone, 1-1-dichloropropanone, dichloroacetonitrile and chloroform were the predominant DBPs in the freshwater pool.

In Ames test, the mutagenicity of the freshwater pool was higher than the tested seawater pool. This observation can be explained by the considerably more important contents of DBPs in the freshwater pool compared to the seawater pool. The mutagenicity of both pool waters decreased in the presence of the metabolic fraction S9 mix, implying the reduction of toxicity of the mutagenic compounds when metabolized. These findings highlight the importance of reducing the formation of DBPs or enhancing their elimination to maintain the chemical safety of swimming pool water.

\section{Acknowledgement}

Tarek Manasfi acknowledges the Doctoral School of "Environmental Sciences" (ED251) at AixMarseille University and the French Ministry of Higher Education and Research for his doctoral scholarship. 


\section{REFERENCES}

ANSES (French Agency for Food, Environmental and Occupational Health and Safety), 2011. Health Risk Assessment in Swimming Pools. Part.1: public swimming pools. https://www.anses.fr/sites/default/files/documents/EAUX2007sa0409Ra.pdf

Baudisch, C., Pansch, G., Prösch, J., Puchert W., 1997. Determination of volatile halogenated hydrocarbons in chlorinated swimming pool water. Research report. Außenstelle Schwerin, Landeshygieneinstitut Mecklenburg-Vorpommern (in German).

Beech, J. a., Diaz, R., Ordaz, C., Palomeque, B., 1980. Nitrates, chlorates and trihalomethanes in swimming pool water. Am. J. Public Health 70, 79-82. doi:10.2105/AJPH.70.1.79

Bougeard, C.M.M., Goslan, E.H., Jefferson, B., Parsons, S.A., 2010. Comparison of the disinfection by-product formation potential of treated waters exposed to chlorine and monochloramine. Water Res. 44, 729-740. doi:10.1016/j.watres.2009.10.008

Boyce, S.D., Hornig, J.F., 1983. Reaction Pathways of Trihalomethane Formation from the Halogenation of Dihydroxyaromatic Model Compounds for Humic Acid. Environ. Sci. Technol. 17, 202-211

Cardador, M.J., Gallego, M., 2015. Haloacetic acids content of fruit juices and soft drinks. Food Chem. 173, 685-693. doi:10.1016/j.foodchem.2014.10.105

Cardador, M.J., Gallego, M., 2011. Haloacetic acids in swimming pools: Swimmer and worker exposure. Environ. Sci. Technol. 45, 5783-5790. doi:10.1021/es103959d

Chowdhury, S., Alhooshani, K., Karanfil, T., 2014. Disinfection byproducts in swimming pool: Occurrences, implications and future needs. Water Res. 53, 68-109. doi:10.1016/j.watres.2014.01.017

Chu, H., Nieuwenhuijsen, M.J., 2002. Distribution and determinants of trihalomethane concentrations in indoor swimming pools. Occup. Environ. Med. 59, 243-247. doi:10.1136/oem.59.4.243

Cimetiere, N., De Laat, J., 2014. Effects of UV-dechloramination of swimming pool water on the formation of disinfection by-products: A lab-scale study. Microchem. J. 112, 34-41. doi:10.1016/j.microc.2013.09.014

Clemens, M., Schöler, H.F., 1992. [Halogenated organic compounds in swimming pool water]. Zentralbl. Hyg. Umweltmed. 193, 91-8.

Crecente, J.M., Santé, I., Díaz, C., Crecente, R., 2012. A multicriteria approach to support the location of thalassotherapy (seawater therapy) resorts: Application to Galicia region, NW Spain. Landsc. Urban Plan. 104, 135-147. doi:10.1016/j.landurbplan.2011.10.010 
De Laat, J., Feng, W., Freyfer, D.A., Dossier-Berne, F., 2011. Concentration levels of urea in swimming pool water and reactivity of chlorine with urea. Water Res. 45, 1139-1146. doi:10.1016/j.watres.2010.11.005

DeMarini, D.M., Shelton, M.L., Warren, S.H., Ross, T.M., Shim, J.Y., Richard, A.M., Pegram, R.A., 1997. Glutathione S-transferase-mediated induction of GC-->AT transitions by halomethanes in Salmonella. Environ. Mol. Mutagen. 30, 440-7.

Domino, M.M., Pepich, B. V., Munch, D.J., Fair, P.S., Xie, Y., 2003. METHOD 552.3 DETERMINATION OF HALOACETIC ACIDS AND DALAPON IN DRINKING WATER BY LIQUID-LIQUID MICROEXTRACTION, DERIVATIZATION, AND GAS CHROMATOGRAPHY WITH ELECTRON CAPTURE DETECTION. Environ. Prot. Agency, Cincinnati, $\mathrm{OH}$.

Escobar-Hoyos, L.F., Hoyos-Giraldo, L.S., Londoño-Velasco, E., Reyes-Carvajal, I., SaavedraTrujillo, D., Carvajal-Varona, S., Sánchez-Gómez, A., Wagner, E.D., Plewa, M.J., 2013. Genotoxic and clastogenic effects of monohaloacetic acid drinking water disinfection byproducts in primary human lymphocytes. Water Res. 47, 3282-3290. doi:10.1016/j.watres.2013.02.052

Fantuzzi, G., Righi, E., Predieri, G., Ceppelli, G., Gobba, F., Aggazzotti, G., 2001. Occupational exposure to trihalomethanes in indoor swimming pools. Sci. Total Environ. 264, 257-265.

Fantuzzi, G., Righi, E., Predieri, G., Giacobazzi, P., Mastroianni, K., Aggazzotti, G., 2010. Prevalence of ocular, respiratory and cutaneous symptoms in indoor swimming pool workers and exposure to disinfection by-products (DBPs). Int. J. Environ. Res. Public Health 7, 1379-1391. doi:10.3390/ijerph7041379

Farré, M.J., Day, S., Neale, P. a., Stalter, D., Tang, J.Y.M., Escher, B.I., 2013. Bioanalytical and chemical assessment of the disinfection by-product formation potential: Role of organic matter. Water Res. 47, 5409-5421. doi:10.1016/j.watres.2013.06.017

Font-Ribera, L., Kogevinas, M., Zock, J.P., Gómez, F.P., Barreiro, E., Nieuwenhuijsen, M.J., Fernandez, P., Lourencetti, C., Pérez-Olabarría, M., Bustamante, M., Marcos, R., Grimalt, J.O., Villanueva, C.M., 2010. Short-term changes in respiratory biomarkers after swimming in a chlorinated pool. Environ. Health Perspect. 118, 1538-1544. doi:10.1289/ehp.1001961

Ged, E.C., Boyer, T.H., 2014. Effect of seawater intrusion on formation of bromine-containing trihalomethanes and haloacetic acids during chlorination. Desalination 345, 85-93. doi:10.1016/j.desal.2014.04.021

Glauner, T., Waldmann, P., Frimmel, F.H., Zwiener, C., 2005. Swimming pool water Fractionation and genotoxicological characterization of organic constituents. Water Res. 39, 4494-4502. doi:10.1016/j.watres.2005.09.005 
Hansen, K.M.S., Willach, S., Antoniou, M.G., Mosbæk, H., Albrechtsen, H.-J., Andersen, H.R., 2012. Effect of $\mathrm{pH}$ on the formation of disinfection byproducts in swimming pool water - Is less THM better? Water Res. 46, 6399-6409. doi:10.1016/j.watres.2012.09.008

Heeb, M.B., Criquet, J., Zimmermann-Steffens, S.G., von Gunten, U., 2014. Oxidative treatment of bromide-containing waters: Formation of bromine and its reactions with inorganic and organic compounds - A critical review. Water Res. 48, 15-42.

doi:10.1016/j.watres.2013.08.030

Hinckley, A.F., Bachand, A.M., Reif, J.S., 2005. Late pregnancy exposures to disinfection byproducts and growth-related birth outcomes. Environ. Health Perspect. 113, 1808-1813. doi:10.1289/ehp. 8282

Hsu, C.-H., Jeng, W.-L., Chang, R.-M., Chien, L.-C., Han, B.-C., 2001. Estimation of Potential Lifetime Cancer Risks for Trihalomethanes from Consuming Chlorinated Drinking Water in Taiwan. Environ. Res. 85, 77-82. doi:10.1006/enrs.2000.4102

Hua, G., Reckhow, D.A., Kim, J., 2006. Effect of Bromide and Iodide Ions on the Formation and Speciation of Disinfection Byproducts during Chlorination. Environ. Sci. Technol. 40, 30503056. doi:10.1021/es0519278

Jain, S.R., Soundararajan, S., 1964. The dipole moments and molecular structure of chloral and bromal hydrates. Tetrahedron 20,1589-1592. doi:10.1016/S0040-4020(01)99155-0

Kanan, A., Karanfil, T., 2011. Formation of disinfection by-products in indoor swimming pool water: The contribution from filling water natural organic matter and swimmer body fluids. Water Res. 45, 926-932. doi:10.1016/j.watres.2010.09.031

Keuten, M.G. a, Schets, F.M., Schijven, J.F., Verberk, J.Q.J.C., van Dijk, J.C., 2012. Definition and quantification of initial anthropogenic pollutant release in swimming pools. Water Res. 46, 3682-3692. doi:10.1016/j.watres.2012.04.012

Keuten, M.G.A., Peters, M.C.F.M., Daanen, H.A.M., de Kreuk, M.K., Rietveld, L.C., van Dijk, J.C., 2014. Quantification of continual anthropogenic pollutants released in swimming pools. Water Res. 53, 259-70. doi:10.1016/j.watres.2014.01.027

Kim, H., Shim, J., Lee, S., 2002. Formation of disinfection by-products in chlorinated swimming pool water. Chemosphere 46, 123-130. doi:10.1016/S0045-6535(00)00581-6

Kogevinas, M., Villanueva, C.M., Font-Ribera, L., Liviac, D., Bustamante, M., Espinoza, F., Nieuwenhuijsen, M.J., Espinosa, A., Fernandez, P., Demarini, D.M., Grimalt, J.O., Grummt, T., Marcos, R., 2010. Genotoxic effects in swimmers exposed to disinfection by-products in indoor swimming pools. Environ. Health Perspect. 118, 1531-1537.

doi:10.1289/ehp.1001959 
Koudjonou, B.K., LeBel, G.L., 2006. Halogenated acetaldehydes: analysis, stability and fate in drinking water. Chemosphere 64, 795-802. doi:10.1016/j.chemosphere.2005.10.063

Lee, J., Jun, M.J., Lee, M.H., Lee, M.H., Eom, S.W., Zoh, K.D., 2010. Production of various disinfection byproducts in indoor swimming pool waters treated with different disinfection methods. Int. J. Hyg. Environ. Health 213, 465-474. doi:10.1016/j.ijheh.2010.09.005

Lifongo, L.L., Bowden, D.J., Brimblecombe, P., 2010. Thermal degradation of haloacetic acids in water. Int. J. 5, 738-747.

Liviac, D., Wagner, E.D., Mitch, W. a., Altonji, M.J., Plewa, M.J., 2010. Genotoxicity of water concentrates from recreational pools after various disinfection methods. Environ. Sci. Technol. 44, 3527-3532. doi:10.1021/es903593w

Lourencetti, C., Grimalt, J.O., Marco, E., Fernandez, P., Font-Ribera, L., Villanueva, C.M., Kogevinas, M., 2012. Trihalomethanes in chlorine and bromine disinfected swimming pools: Air-water distributions and human exposure. Environ. Int. 45, 59-67. doi:10.1016/j.envint.2012.03.009

Manasfi, T., Storck, V., Ravier, S., Demelas, C., Coulomb, B., Boudenne, J.-L., 2015. Degradation Products of Benzophenone-3 in Chlorinated Seawater Swimming Pools. Environ. Sci. Technol. 49, 9308-9316. doi:10.1021/acs.est.5b00841

Neale, P. a., Antony, A., Bartkow, M.E., Farré, M.J., Heitz, A., Kristiana, I., Tang, J.Y.M., Escher, B.I., 2012. Bioanalytical assessment of the formation of disinfection byproducts in a drinking water treatment plant. Environ. Sci. Technol. 46, 10317-10325. doi:10.1021/es302126t

Nieuwenhuijsen, M.J., Toledano, M.B., Eaton, N.E., Fawell, J., Elliott, P., 2000. Chlorination disinfection byproducts in water and their association with adverse reproductive outcomes: a review. Occup. Environ. Med. 57, 73-85. doi:10.1136/oem.57.2.73

Parinet, J., Tabaries, S., Coulomb, B., Vassalo, L., Boudenne, J.L., 2012. Exposure levels to brominated compounds in seawater swimming pools treated with chlorine. Water Res. 46, 828-836. doi:10.1016/j.watres.2011.11.060

Plewa, M.J., Wagner, E.D., Muellner, M.G., Hsu, K.-M., Richardson, S.D., 2008. Comparative mammalian cell toxicity of N-DBPs and C-DBPs. Disinfection By-Products in Drinking Water, ACS Symposium Series. American Chemical Society, Washington, DC. doi:10.1021/bk-2008-0995

Richardson, S., Plewa, M., Wagner, E., Schoeny, R., Demarini, D., 2007. Occurrence, genotoxicity, and carcinogenicity of regulated and emerging disinfection by-products in drinking water: A review and roadmap for research. Mutat. Res. 636, 178-242. doi:10.1016/j.mrrev.2007.09.001 
Richardson, S. D., Thruston, A. D., Krasner, S. W., Weinberg, H. S., Miltner, R. J., Schenck, K. M., Narotsky, M. G., McKague, A. B., Simmons, J. E., 2008. Integrated disinfection byproducts mixtures research: Comprehensive characterization of water concentrates prepared from chlorinated and ozonated/postchlorinated drinking water. J. Toxicol. Environ. Health $71,1165-1186$.

Richardson, S.D., DeMarini, D.M., Kogevinas, M., Fernandez, P., Marco, E., Lourencetti, C., Ballesté, C., Heederik, D., Meliefste, K., McKague, A.B., Marcos, R., Font-Ribera, L., Grimalt, J.O., Villanueva, C.M., 2010. What's in the Pool? A Comprehensive Identification of Disinfection By-products and Assessment of Mutagenicity of Chlorinated and Brominated Swimming Pool Water. Environ. Health Perspect. 118, 1523-1530.

doi:10.1289/ehp.1001965

Righi, E., Fantuzzi, G., Predieri, G., Aggazzotti, G., 2014. Bromate, chlorite, chlorate, haloacetic acids, and trihalomethanes occurrence in indoor swimming pool waters in Italy. Microchem. J. 113, 23-29. doi:10.1016/j.microc.2013.11.007

Rook, J.J., 1980. Water Chlorination: Environmental Impact and Health Effects. Jolley, R.L., et al., Eds., Ann Arbor Science Publishers: Ann Arbor, MI, Vol. 3, 85-98

Schwartz, M.L., 2005. Encyclopedia of Coastal Science. Springer, Dordrecht, The Netherlands.

Simard, S., Tardif, R., Rodriguez, M.J., 2013. Variability of chlorination by-product occurrence in water of indoor and outdoor swimming pools. Water Res. 47, 1763-1772. doi:10.1016/j.watres.2012.12.024

Singer, P.C., 1999. Humic substances as precursors for potentially harmful disinfection byproducts. Water Sci. Technol. 40, 25-30. doi:10.1016/S0273-1223(99)00636-8

Takanashi, H., Kishida, M., Nakajima, T., Ohki, A., Akiba, M., Aizawa, T., 2009. Surveying the mutagenicity of tap water to elicit the effects of purification processes on Japanese tap water. Chemosphere 77, 434-439. doi:10.1016/j.chemosphere.2009.06.038

Teo, T.L.L., Coleman, H.M., Khan, S.J., 2015. Chemical contaminants in swimming pools: Occurrence, implications and control. Environ. Int. 76, 16-31. doi:10.1016/j.envint.2014.11.012

Thacker, N.P., Nitnaware, V., 2003. Factors influencing formation of trihalomethanes in swimming pool water. Bull. Environ. Contam. Toxicol. 71, 633-640. doi:10.1007/s00128$003-8650-2$

Usepa, 1995. Determination of chlorination disinfection byproducts, chlorinated solvents, and halogenated pesticides/herbicides in drinking water by liquid-liquid extraction and gas chromatography with electron-capture detection. Rev. 1. 
Villanueva, C.M., Cantor, K.P., Cordier, S., Jaakkola, J.J.K., King, W.D., Lynch, C.F., Porru, S., Kogevinas, M., 2004. Disinfection Byproducts and Bladder Cancer. Epidemiology 15, 357367. doi:10.1097/01.ede.0000121380.02594.fc

Villanueva, C.M., Cantor, K.P., Grimalt, J.O., Malats, N., Silverman, D., Tardon, A., GarciaClosas, R., Serra, C., Carrato, A., Castaño-Vinyals, G., Marcos, R., Rothman, N., Real, F.X., Dosemeci, M., Kogevinas, M., 2007. Bladder cancer and exposure to water disinfection byproducts through ingestion, bathing, showering, and swimming in pools. Am. J. Epidemiol. 165, 148-156. doi:10.1093/aje/kwj364

Wang, H., Liu, D., Zhao, Z., Cui, F., Zhu, Q., Liu, T., 2010. Factors influencing the formation of chlorination brominated trihalomethanes in drinking water. J. Zhejiang Univ. Sci. A 11, 143150. doi:10.1631/jzus.A0900343

Wang, W., Qian, Y., Boyd, J.M., Wu, M., Hrudey, S.E., Li, X.-F., 2013. Halobenzoquinones in Swimming Pool Waters and Their Formation from Personal Care Products. Environ. Sci. Technol. 130313084110007. doi:10.1021/es304938x

Weinberg, H.S., Krasner, S.W., Richardson, S.D., Thruston, a D., 2002. EPA The Occurrence of Disinfection By-Products (DBPs) of Health Concern in Drinking Water: Results of a Nationwide DBP Occurrence Study 462p. doi:EPA/600/R-02/068

Westerhoff, P., Chao, P., Mash, H., 2004. Reactivity of natural organic matter with aqueous chlorine and bromine. Water Res. 38, 1502-1513. doi:10.1016/j.watres.2003.12.014

World Health Organization, 2006. Guidelines for Safe Recreational Water Environments. Vol. 2, Swimming Pools and Similar Environments; WHO Press: Geneva.

Wu, W.W., Chadik, P.A., 1998. Effect of Bromide Ion on Haloacetic Acid Formation during Chlorination of Biscayne Aquifer Water. J. Environ. Eng. 124, 932-938. doi:10.1061/(ASCE)0733-9372(1998)124:10(932)

Xu, X., Mariano, T.M., Laskin, J.D., Weisel, C.P., 2002. Percutaneous absorption of trihalomethanes, haloacetic acids, and haloketones. Toxicol. Appl. Pharmacol. 184, 19-26. doi:10.1016/S0041-008X(02)99494-9

Xue, S., Zhao, Q.-L., Wei, L.-L., Jia, T., 2008. Effect of bromide ion on isolated fractions of dissolved organic matter in secondary effluent during chlorination. J. Hazard. Mater. 157, 25-33. doi:10.1016/j.jhazmat.2007.12.071

Yeh, R.Y.L., Farré, M.J., Stalter, D., Tang, J.Y.M., Molendijk, J., Escher, B.I., 2014. Bioanalytical and chemical evaluation of disinfection by-products in swimming pool water. Water Res. 59, 172-184. doi:10.1016/j.watres.2014.04.002 
Zhang, X., Minear, R. a., 2002. Decomposition of trihaloacetic acids and formation of the corresponding trihalomethanes in drinking water. Water Res. 36, 3665-3673.

doi:10.1016/S0043-1354(02)00072-6

Zwiener, C., Richardson, S.D., De Marini, D.M., Grummt, T., Glauner, T., Frimmel, F.H., 2007. Drowning in disinfection byproducts? Assessing swimming pool water. Environ. Sci. Technol. 41, 363-372. doi:10.1021/es062367v 


\section{ANNEXES}

Section 1 Physicochemical parameters of the pools under study

Section 2 Experimental Methods

2.1 Preparation of standard solutions

2.2 Sample Treatment

2.2.1 Analysis of THMs, HANs, HKs, and THAs

\subsubsection{Analysis of HAAs}

2.3 Detection Limits and Minimum Reporting Levels

Section 3 Analytical Results

2.1 Figure S1

2.2 Figure $\mathrm{S} 2$

2.3 Figure S3 


\section{Section 1: Physicochemical Parameters}

Table S1. Results of all the measured physicochemical parameters in the four swimming pools.

\begin{tabular}{|c|c|c|c|c|}
\hline \multirow[t]{3}{*}{ Establishment Code } & \multicolumn{2}{|c|}{ E1 } & \multicolumn{2}{|c|}{ E2 } \\
\hline & Freshwater & Seawater & Seawater & Seawater \\
\hline & Pool & Pool & Pool (1) & Pool (2) \\
\hline \multicolumn{5}{|l|}{ Physicochemical Parameters } \\
\hline $\mathrm{T}\left({ }^{\circ} \mathrm{C}\right)$ & 29.40 & 33.20 & 30.90 & 33.40 \\
\hline$\underline{\mathrm{pH}}$ & 7.00 & 8.54 & 8.46 & 8.32 \\
\hline Salinity (PSU) & 1.15 & 51.87 & 44.55 & 44.32 \\
\hline Bromide (mg/L) & 0.2 & 90.5 & 72.0 & 74.1 \\
\hline TOC $(\mathrm{mg} / \mathrm{L})$ & 11.52 & 11.88 & 10.88 & 11.82 \\
\hline Free Chlorine mg/L & 1.55 & 1.39 & 1.16 & 1.05 \\
\hline Combined Chlorine $(\mathrm{mg} / \mathrm{L})$ & 0.29 & 0.11 & 0.16 & 0.10 \\
\hline $\mathrm{O}_{2}(\%$ saturation $)$ & 99.9 & 101.0 & 101.6 & 101.3 \\
\hline $\mathrm{EC}(\mu \mathrm{S} / \mathrm{cm})$ & 2288 & 75000 & 65600 & 73200 \\
\hline TDS (mg/L) & 1483 & 48730 & 42650 & 46848 \\
\hline $\mathrm{ORP}(\mathrm{mV})$ & 512 & 705 & 697 & 655 \\
\hline
\end{tabular}

EC: Electrical Conductivity reported in microSiemens per centimeter

Salinity expressed in Practical Salinity Unit (PSU)

Total Dissolved Solid (TDS) expressed in $\mathrm{mg} / \mathrm{L}$

ORP: Oxidation Reduction Potential expressed in millivolts ( $\mathrm{mV}$ ) 


\section{Section 2: Experimental Methods}

\subsection{Preparation of Standard Solutions}

Commercially available certified standards and mixes were purchased (Table S2).

These standards were used to prepare stock solutions in methyl tert butyl ether (MTBE) or methanol. In their turn, stock solutions were used to spike either pure water (for chlorinated DBPs) or synthetic seawater (for brominated DBPs) to create the calibration standards used to generate calibration curves for each compound of interest. At least 5 calibration standards were used to prepare the initial calibration curve. The concentrations of the standards were prepared to span the range of concentrations expected in the field samples. Synthetic seawater was prepared according to the ASTM

International standard practice for the preparation of substitute ocean water (method D1141-98, 2013) (Table S3 summarizes the artificial seawater content). 
Table S2. Commercially available standards used for calibrations

\begin{tabular}{l|l}
\hline Mixes/Products & Compound \\
\hline EPA 551B Halogenated Volatiles & Bromochloroacetonitrile, Chloropicrin \\
Supelce 4-8046 & Dibromoacetonitrile, Dichloroacetonitrile \\
$2000 \mu \mathrm{g} / \mathrm{mL}$ in acetone & 1,1 -Dichloropropanone, Trichloroacetonitrile \\
& $1,1,1$-Trichloropropanone \\
\hline EPA 501/601 Trihalomethanes Calibration Mix & Chloroform, Bromodichloromethane \\
Supelco 47904 & Dibromochloromethane, Bromoform \\
$100 \mu \mathrm{g} / \mathrm{mL}$ each component in methanol & \\
\hline Chloral hydrate solution & Chloral hydrate \\
Supelco 47335-U & \\
$1000 \mu \mathrm{g} / \mathrm{mL}$ in acetonitrile & Bromoacetic acid, Bromochloroacetic acid \\
\hline Tribremoacetaldehyde & Dromodichloroacetic, acid, Chloroacetic acid \\
Aldrich T48003 & Tribromoacetaldehyde, \\
$97 \%$ &
\end{tabular}


Table S3. Artificial seawater content

\begin{tabular}{lr}
\hline Salt & $\begin{array}{r}\text { Amount } \\
(\mathrm{g} / \mathrm{L})\end{array}$ \\
\hline $\mathrm{NaCl}$ & 24.53 \\
$\mathrm{MgCl}_{2}, 7 \mathrm{H}_{2} \mathrm{O}$ & 5.2 \\
$\mathrm{Na}_{2} \mathrm{SO}_{4}$ & 4.09 \\
$\mathrm{CaCl}_{2}$ & 1.16 \\
$\mathrm{KCl}$ & 0.695 \\
$\mathrm{NaHCO}_{3}$ & 0.201 \\
$\mathrm{H}_{3} \mathrm{BO}_{3}$ & 0.027 \\
$\mathrm{SrCl}_{2}$ & 0.025 \\
$\mathrm{NaE}$ & 0.003 \\
$\mathrm{KBr}$ & 0.101 \\
\hline
\end{tabular}

Artificial seawater for chlorination experiments has been reconstituted according to ASTM International standard practice for the preparation of substitute ocean water (method D1141-98, 2013). Contents presented correspond to amounts needed for the preparation of $1 \mathrm{~L}$ of seawater. 


\subsection{Sample treatment}

\subsubsection{Analysis of THMs, HANs, HKs, and THAs}

EPA method 551.1 was used with slight modifications for the analysis of these classes of DBPs (USEPA method 551.1, 1995). Samples collected in $65 \mathrm{~mL}$ glass vials with PTFE-lined screw caps were quenched using a solution of ascorbic acid and few drops of sulfuric acid were added to lower $\mathrm{pH}$ to 4-5 in order to stabilize certain DBPs by inhibiting base-catalyzed degradation. Liquid-liquid extraction (LLE) of samples $(50 \mathrm{~mL}$ ) was carried out by applying $5 \mathrm{~mL}$ of the solvent MTBE and shaking vigorously by hand for $3 \mathrm{~min}$. Then, $1 \mathrm{~mL}$ of the extract was transferred to autosampler vial and $10 \mu \mathrm{L}$ of the internal standard (IS) 1,2,3-trichloropropane (analytical standard, Supleco) were added. $1 \mu \mathrm{L}$ of the extract was injected for GCECD analysis. The instrument used for analysis of DBPs was a Perkin Elmer Clarus 580 GC-ECD (Norwalk, CT, USA).

A capillary column DB5-ms $(30 \mathrm{~m} \times 0.25 \mathrm{~mm} \times 1 \mu \mathrm{m})$ was used for the separation of analytes.

Helium 5.0 was used as a carrier gas at a programmed flow of $1 \mathrm{ml} / \mathrm{min}$ and nitrogen as make-up gas at a flow of $30 \mathrm{ml} / \mathrm{min}$.

The GC oven temperature was programmed as follows:

(1) Held at $35^{\circ} \mathrm{C}$ for $22 \mathrm{~min}$

(2) Increased to $145^{\circ} \mathrm{C}$ at $20^{\circ} \mathrm{C} / \mathrm{min}$ and held at $145^{\circ} \mathrm{C}$ for $2 \mathrm{~min}$

(3) Increased to $225^{\circ} \mathrm{C}$ at $20^{\circ} \mathrm{C} / \mathrm{min}$ and held for $15 \mathrm{~min}$

(4) Increased to $260^{\circ} \mathrm{C}$ at $10^{\circ} \mathrm{C} / \mathrm{min}$ and held for $2 \mathrm{~min}$.

Injector Temperature: $200^{\circ} \mathrm{C}$

Detector Temperature: $290^{\circ} \mathrm{C}$

Injection was done in splitless mode, but the instrument was programmed to go into split mode (ratio 30:1) after 3 minutes following injection. 


\subsubsection{Analysis of HAAs}

For the analysis of haloacetic acids (HAA), the instructions of to U.S.EPA 552.3, 2003 (Domino et al., 2003) were followed with slight modifications. Samples $(65 \mathrm{~mL})$ collected in glass vials with PTFE-lined screw caps were quenched using a solution of ascorbic acid. To a sample aliquot of $50 \mathrm{~mL}$, the surrogate 2,3-dibromopropanoic acid was added. Then, sulfuric acid of analytical grade reagent (Fisher Scientific, UK) was added to lower the $\mathrm{pH}$ to 0.5 or less. LLE was then performed by adding MTBE $(5 \mathrm{~mL})$ and shaking for $3 \mathrm{~min}$ by hand vigorously. 1,2,3-trichloropropanone was added as IS. The organic extract containing the HAAs was then methylated with acidic methanol to form the methyl esters of the HAAs. This was performed by transferring $3 \mathrm{~mL}$ of the MTBE extract to conical tubes and then adding $3 \mathrm{~mL}$ of $10 \%$ sulfuric acid in methanol to each tube. The tubes were then capped and put in a water bath at $50{ }^{\circ} \mathrm{C}$ for 2 hours. Afterwards, $7 \mathrm{~mL}$ of a $150 \mathrm{~g} / \mathrm{L}$ sodium sulfate solution were added to each tube, which were vortexed to ensure equilibration between the two phases. Phases were allowed to settle fully, but not more than a few minutes. The acidic aqueous methanol phase was removed from each tube and discarded. $4 \mathrm{~mL}$ of saturated sodium bicarbonate solution were added gradually in 4 steps ( $1 \mathrm{~mL}$ each time). $1 \mathrm{~mL}$ of the MTBE layer was transferred to an autosampler vial Extracts containing the esters were then neutralized by adding a saturated sodium bicarbonate solution and then submitted to GC-ECD analysis according. 2,3dibromopropanoic acid (Supelco Analytical, Bellefonte, PA, USA) was used as surrogate and 1,2,3chloropropane (analytical standard, Supelco) was used as IS.

Helium 5.0 was used as a carrier gas at a programmed flow of $1 \mathrm{ml} / \mathrm{min}$ and nitrogen as make-up gas at a flow of $30 \mathrm{ml} / \mathrm{min}$.

The GC oven temperature was programmed as follows:

(1) Held at $40^{\circ} \mathrm{C}$ for $10 \mathrm{~min}$

(2) Increased to $75^{\circ} \mathrm{C}$ at $5{ }^{\circ} \mathrm{C} / \mathrm{min}$ and held at $75^{\circ} \mathrm{C}$ for $15 \mathrm{~min}$

(3) Increased to $100{ }^{\circ} \mathrm{C}$ at $5^{\circ} \mathrm{C} / \mathrm{min}$ and held at $100{ }^{\circ} \mathrm{C}$ for $5 \mathrm{~min}$ 
(4) Increased to $135^{\circ} \mathrm{C}$ at $5^{\circ} \mathrm{C} / \mathrm{min}$ and held for $10 \mathrm{~min}$

The injector temperature was programmed as follows:

(1) Held at $55^{\circ} \mathrm{C}$ for $10 \mathrm{~min}$

(2) Increased to $250{ }^{\circ} \mathrm{C}$ at $200^{\circ} \mathrm{C} / \mathrm{min}$ and held at $250{ }^{\circ} \mathrm{C}$ for $40 \mathrm{~min}$

(3) Decreased to $55^{\circ} \mathrm{C}$ at $200{ }^{\circ} \mathrm{C} / \mathrm{min}$ and held till the end of run

Detector Temperature: $260^{\circ} \mathrm{C}$

Injection: splitless mode with instrument programmed to go into split mode after 3 min following injection, split ratio 30:1

\subsection{Detection Limits (DL) and Minimum Reporting Levels (MRL)}

The limits of detection (DL) for each analyte were calculated by injecting at least 7 replicates of a fortified solution at a concentration estimated to be near the DL which were extracted and analyzed over 3 days.

DLs were calculated using the equation:

$D L=S \times t(n-1,1-\alpha=0.99)$

where

$S=$ standard deviation of the replicate analyses

$t(n-1,1-\alpha=0.99)=$ Students $t$ value for the $99 \%$ confidence level with $n-1$ degrees of freedom ( 3.143

for 7 replicates)

$\mathrm{n}=$ number of replicates, and

The MRLs were established as three times the DLs. Detected concentrations below the MRL were not reported.

The DLs and MRLs of the analytes are listed in table S4. 
Table S4. Limits of detection (DL) and minimum reporting levels (MRL) of the analytes

\begin{tabular}{|c|c|c|}
\hline Compound & $\mathrm{DL}(\mu \mathrm{g} / \mathrm{L})$ & MRL $(\mu \mathrm{g} / \mathrm{L})$ \\
\hline Chloreforma & 0.8 & 2.4 \\
\hline Bromedichloromethane & 0.3 & 0.9 \\
\hline Dibromochloromethane & 0.2 & 0.6 \\
\hline Bromeform & 0.2 & 0.6 \\
\hline Dichloroacetonitrile & 0.2 & 0.6 \\
\hline Trichloroacetonitrile & 0.3 & 1.2 \\
\hline Bromechloroacetenitrile & 0.3 & 0.9 \\
\hline Dibromoacetonitrile & 0.2 & 0.6 \\
\hline 1,1-Dichloropropanone & 0.6 & 1.8 \\
\hline 1,1,1-Trichloropropanone & 0.9 & 2.7 \\
\hline Monochloroacetic acid & 1.2 & 3.4 \\
\hline Monobremoacetic acid & 0.9 & 2.7 \\
\hline Dichloroacetic acid & 0.7 & 2.1 \\
\hline Irichloroacetic acid & 0.5 & 1.5 \\
\hline Bromechloroacetic acid & 0.5 & 1.5 \\
\hline Dibromoacetic acid & 0.4 & 1.2 \\
\hline Bromodichloroacetic acid & 0.6 & 1.8 \\
\hline Dibromochlorgacetic acid & 0.5 & 1.5 \\
\hline Tribromoacetic acid & 1.0 & 3.0 \\
\hline Chloral hydrate & 0.2 & 0.6 \\
\hline Bromal hydrate & 0.1 & 0.3 \\
\hline Chloropicrine & 0.3 & 0.9 \\
\hline
\end{tabular}




\section{Section 3: Analytical Results}

Figure S1 - The distribution of THMs in the pools under study. THM-4 represents the sum of the levels of the four THMs in each pool.

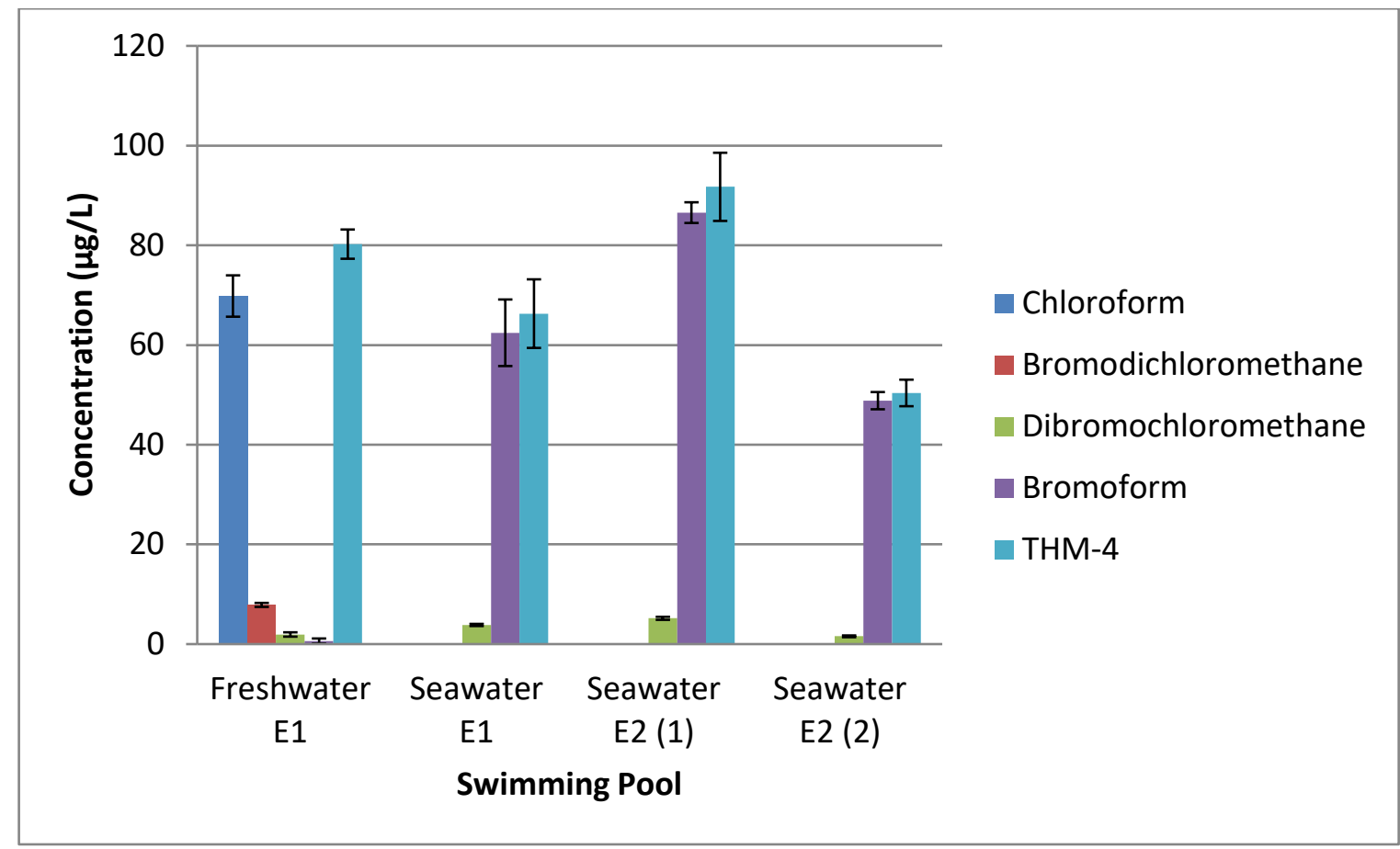

Figure S2 - The levels of HANs in the swimming pools. Total HAN represents the sum of concentrations of individual HANs identified in each pool. 


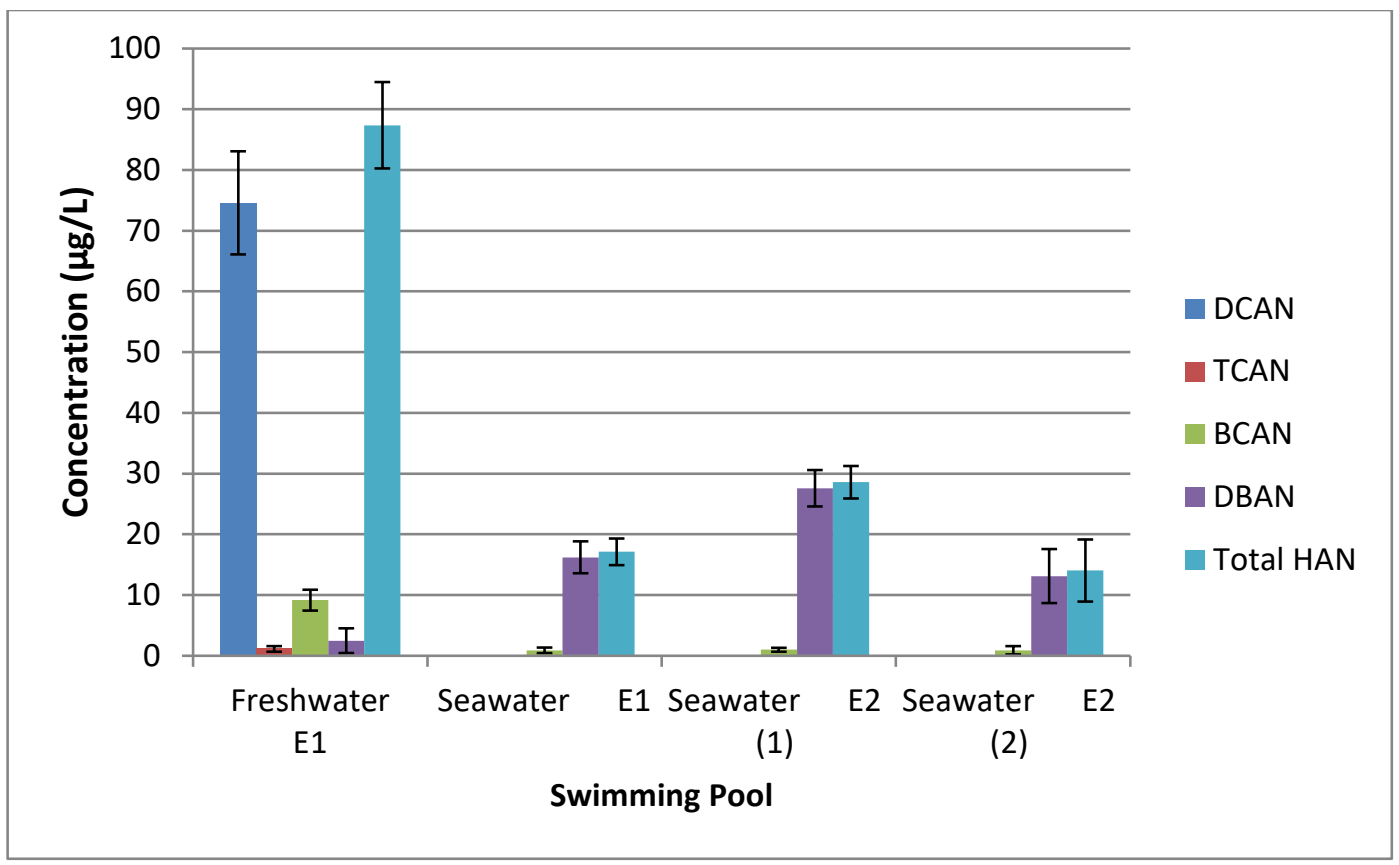

Figure S3 - The levels of the trihaloacetaldehydes (chloral hydrate and bromal hydrate) in the studied pools. On the $y$-axis, the concentration (in $\mu \mathrm{g} / \mathrm{L}$ ) is represented on a logarithmic scale.

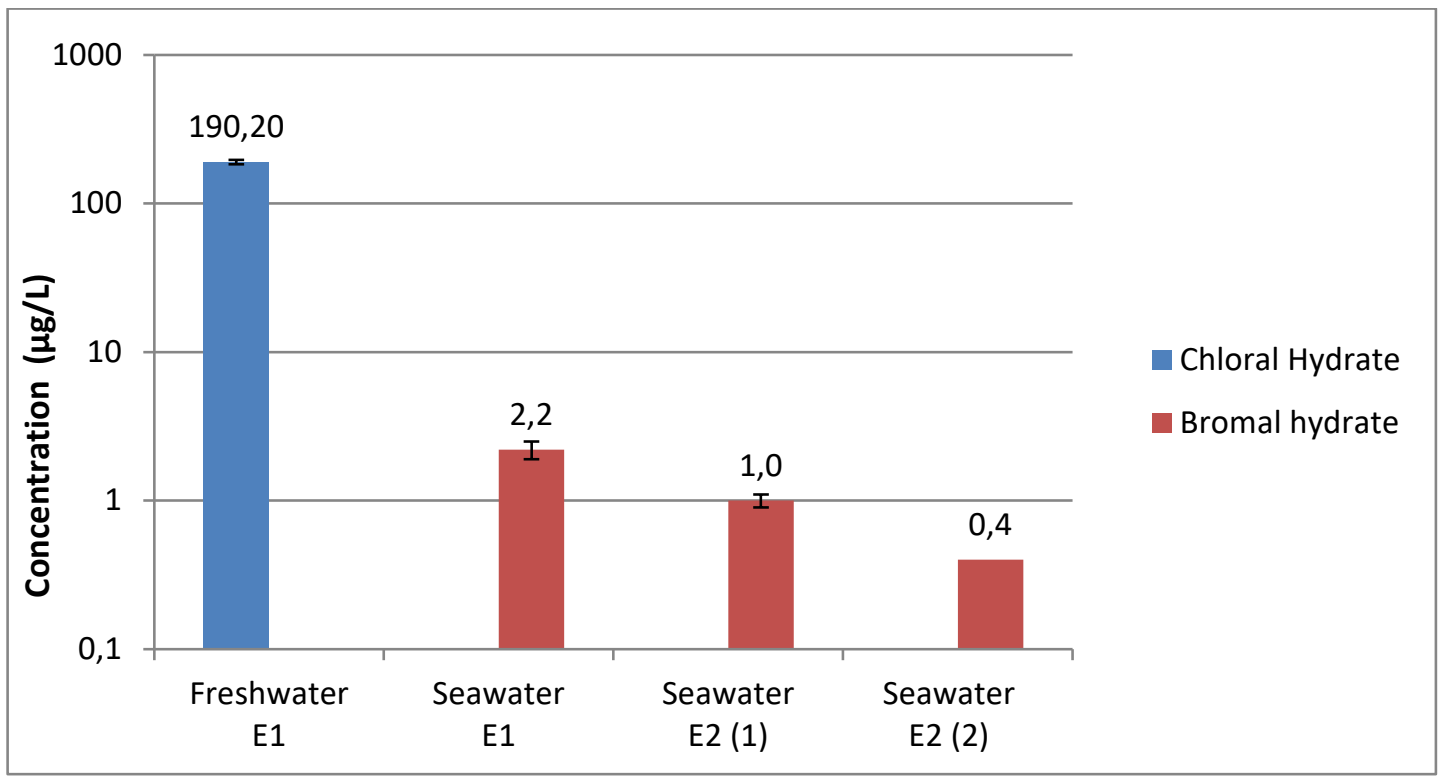

\section{REFERENCES}


Domino, M.M., Pepich, B. V., Munch, D.J., Fair, P.S., Xie, Y., 2003. METHOD 552.3 DETERMINATION OF HALOACETIC ACIDS AND DALAPON IN DRINKING WATER BY LIQUID-LIQUID MICROEXTRACTION, DERIVATIZATION, AND GAS CHROMATOGRAPHY WITH ELECTRON CAPTURE DETECTION. Environ. Prot. Agency, Cincinnati, $\mathrm{OH}$.

Munch, D. J., and D. P. Hautman., 1995 Method 551.1. Determination of Chlorination Disinfection By products, Chlorinated Solvents, and Halogenated Pesticides/Herbicides in Drinking Water by Liquid-Liquid Extraction and Gas Chromatography with Electron Capture Detection. Methods for the Determination of Organic Compounds in Drinking Water, Supplement III, EPA-600/R-95/131. Cincinnati, OH: U.S. Environmental Protection Agency, Cincinnati, $\mathrm{OH}$. 